\title{
INCÊNDIO ESTRUTURAL EM ARMAZÉM ATACADISTA: UM ESTUDO DE CASO FACE A ANÁLISE CRÍTICA OPERACIONAL DE ESPECIALISTAS
}

Reycilane Carvalho Silva

Tiago Costa Chaves ${ }^{2}$

\section{RESUMO}

A este trabalho se interessa em compreender a influência da não regulamentação numa edificação quando se instaura um incêndio de grandes proporções. O estudo teve como principal objetivo investigar a influência do não cumprimento dessas regulamentações numa comercial atacadista ${ }^{3}$ associado a perspectiva de bombeiros que atuaram no incêndio como especialistas em quatro frentes de trabalho: Curso de Operações em Incêndio (COI), Instrutor Flashover, Condutor de Veículo de Incêndio e Perícia de Incêndio. A condução da pesquisa permitiu investigar a existência de relações de insalubridade, periculosidade e penosidade no trabalho de combate a incêndio, bem como os problemas ocorridos da não regulamentação empresarial. A pesquisa qualitativa contou com a realização de análise documental, entrevistas em profundidade intencional (02 bombeiros especializados em COI, 02 Instrutores Flashover, 02 Peritos em Incêndio e 01 condutor de veículo de Incêndio) e análises de imagens de mídias veiculadas publicamente e acervo digital particular de nossa autoria. Os resultados evidenciaram a influência da não adequação às normas técnicas contra incêndio e pânico como fator preponderante para situação de instabilidade e amplitude do incêndio, contribuindo significativamente para o desgaste ocupacional dos bombeiros.

Palavras-chave: Incêndio; Profissão; Bombeiro e desgaste ocupacional.

\footnotetext{
${ }^{1}$ Doutora em Sociologia do Trabalho pela Universidade Federal de Goiás (UFG) sobre o trabalho militar de bombeiros. Chefe da Seção de Pesquisa em Operações e Tecnologia em Incêndio (SPOTI) do Comando de Operações e tecnologia em Incêndio (COTI) do Corpo de bombeiros Militar de Goiás (CBMGO) e bombeira militar a mais de vinte anos. E-mail: reycechadud@gmail.com

${ }^{2}$ Mestrando em Filosofia Clínica direcionada ao trabalho bombeiro militar pelo Instituto Sendtko (Chapecó-SC) e Comandante do Comando de Operações e Tecnologia em Incêndio (COTI) do Corpo de bombeiros Militar de Goiás (CBMGO), sendo bombeiro militar a mais de dezoito anos. E-mail: tiagocosta2289@gmail.com

${ }^{3}$ A empresa citada é localizada na cidade de Anápolis - Goiás e foi mantido o sigilo de suas informações. O incêndio ocorreu no ano de 2020. Não houve perda de vidas humanas, nem pessoas feridas diretamente pelo referido incêndio.
} 


\title{
FIRE IN WHOLESALE WAREHOUSE: A CASE STUDY IN THE FACE OF CRITICAL OPERATIONAL ANALYSIS OF EXPERTS
}

\begin{abstract}
This work is interested in understanding the influence of non-regulation on a building when a large fire is set up. The main objective of the study was to investigate the influence of non-compliance with these regulations in a wholesale commercial associated with the perspective of firefighters who acted in the fire as specialists on four work fronts: Fire Operations Course (IOC), Flashover Instructor, Fire Vehicle Driver and Fire Expertise. The conduct of the research allowed to investigate the existence of relationships of unhealthiness, dangerousness and hardship in the work of fire fighting, as well as the problems that occurred from non-regulation of business. The qualitative research included documentary analysis, in-depth interviews (02 firefighters specialized in IOC, 02 Instructors Flashover, 02 Fire Experts and 01 fire vehicle driver) and analysis of images of publicly conveyed media and private digital collection of our own. The results showed the influence of non-adequacy to technical standards against fire and panic as a preponderant factor for the situation of instability and amplitude of the fire, contributing significantly to the occupational wear of firefighters.
\end{abstract}

Keywords: fire, profession, fireman and occupational wear. 


\section{INTRODUÇÃO}

O trabalho de combate a incêndios é sem sombra de dúvidas, a atividade que mais descreve a identidade laboral de bombeiros em todo 0 mundo. Historicamente,

A origem do corpo de bombeiros remonta à antiguidade, sendo uma das primeiras organizações encontradas em Roma, na Itália, criadas pelo imperador Augusto por volta de 27 a.C. Os 'vigiles', como eram chamados os primeiros bombeiros, serviam como patrulheiros $\mathrm{e}$ impediam possíveis incêndios, vigiando toda a cidade, principalmente no período noturno. (CHADUD, 2013)

Somada a essa identidade laboral de combate a incêndios, os corpos de bombeiros em todo mundo, sustentam um nível de confiança pública institucional bastante expressivo, chegando a alcançar um patamar de $95 \%$ de reconhecimento social ${ }^{4}$ (NIM, 2016) e, mais ainda no Brasil com 96\% (IBOPE, 2019) de aceitação pública por onze anos consecutivos. O aporte para tamanha positividade pauta-se na perspectiva de trabalho que insere a missão de salva guarda de vidas e bens preventivamente e em decorrência de sinistros.

Desta forma, atualmente a atividade de bombeiros especializada/perita no combate a incêndios preconiza a melhoria de sua capacidade técnica e profissional para melhor servir a comunidade, acompanhando as evoluções no mundo dos negócios, da vida social, riscos diversos e densidade demográfica, sem contar, em todas as possíveis conotações que as mudanças climáticas nos impõem.

\footnotetext{
${ }^{4}$ Disponível em: Worldwide ranking: trust in professions | GfK Compact (nim.org)
} 
Um forte indício de sua capacidade técnica e grau de profissionalização tem sido observado nas últimas décadas, com o crescimento de cursos de especializações criados e efetuados para atender as demandas de ocorrências que a cada ano vem se destacando como necessárias a atividade de bombeiros nas mais diversas áreas de salvamento veicular, terrestre, aquático, altura, desastres, segurança e pânico, perícia de incêndio e primeiros socorros de forma geral. Os chamados experts (FREIDSON, 1988) da área de incêndio concentram um conhecimento multifacetado entre área operacionalizada e desenvolvimento técnico-científico, aparecendo assim como autoridade no tratamento de combate a incêndio.

Diante destas implicações para o trabalho de bombeiro acerca da área especializada de combate a incêndio, este trabalho procura analisar de forma incipiente a relação entre o trabalho de bombeiros em suas mais variadas formas no atendimento a ocorrências de incêndio estrutural num mundo moderno, grassado por um risco variavelmente acentuado, sobremaneira em ambientes que não se adequam as normatizações de segurança e pânico, fator esse primordial para redução dos danos estruturais, humanos e ao meio ambiente da vida em sociedade.

Os incêndios estruturais representam uma preocupação a mais, quando se leva em conta sua capacidade de propagação a outras áreas adjacentes, risco de explosões, contaminação do ar e redes fluviais, dano econômico, social e a vidas. Acrescenta-se a este escopo, o aumento do risco ocupacional gerado aqueles que trabalham diretamente em sua extinção, seja nas primeiras fases do incêndio ou mesmo em sua fase de rescaldo ${ }^{5}$.

$O$ incêndio estrutural em atacadistas representa uma perca material muito grande para o empregador, empregados e sociedade em geral. Afeta

\footnotetext{
${ }^{5}$ Atividade de trabalho dos bombeiros efetuada após o combate ao incêndio, que consiste em procurar novos focos de incêndio, na maioria das vezes, causados por reignição devido a temperatura elevada no local ou evitar que os mesmos, apareçam em locais diferenciados. Consiste num trabalho de reviravolta dos entulhos e escombros, resfriamento por água das camadas mais interiorizadas e afastamento de outros materiais que possam ser envolvidos no incêndio.
} 
abastecimentos de produtos, desenvolvimento econômico e gera transtornos na saúde, segurança e vidas daqueles que são envolvidos direta ou indiretamente nele. Nestes ambientes, também se encontram um número de pessoas considerável representando um risco significativo para a vida desses trabalhadores.

Segundo relatos do proprietário da empresa deste estudo de caso, a perca material ocorrida no incêndio em seu estabelecimento gerou em torno de cem milhões de reais. Não houve feridos, nem mortes. Mas, houveram afetados por ingestão de fumaça nos locais próximos ao evento do incêndio e, também, danos naturais que não puderam ser ainda auferidos.

Sendo assim, o objetivo deste estudo de caso é analisar o incêndio estrutural em armazém atacadista com o objetivo de ressignificar o trabalho de especialistas e peritos diante das adversidades operacionais ocorridas em situações de não adequação destes espaços as normas de segurança contra incêndio e pânico, ressaltando o risco ocupacional, percas materiais e de vidas humanas tanto para quem realiza o combate a incêndio, quanto para quem está envolvido num incêndio com essas categorizações. A escolha do objeto partiu da repercussão que o referido incêndio teve no cenário regional, dos danos ocasionados pela falta de estruturação adequada as normatizações vinculantes e da proporção de perca material auferida pelo empresário.

\section{REFERENCIAL TEÓRICO}

O trabalho de bombeiros é legalmente instituído no Brasil pelo artigo 144 da Constituição Federal (1988) como serviço de "segurança pública, dever do Estado, direito e responsabilidade de todos, é exercida para a preservação da ordem pública e da incolumidade das pessoas e do patrimônio, através dos seguintes órgãos" e em seu Parágrafo $5^{\text {o }}$ salienta que aos "corpos de bombeiros militares, além das atribuições definidas em lei, incumbe a execução de atividades de defesa civil'. 
A Constituição Estadual de Goiás (1989) preconiza em seu artigo 121 que:

A Segurança Pública, dever do Estado, direito e responsabilidade de todos, é exercida para assegurar a preservação da ordem pública, a incolumidade das pessoas, do patrimônio e do meio ambiente e o pleno e livre exercício dos direitos e garantias fundamentais, individuais, coletivos, sociais e políticos, estabelecidos nesta e na Constituição da República, por meio dos seguintes órgãos: III - Corpo de Bombeiros Militar.

Mas é no Artigo 125 da referida Lei, que nossas atividades de trabalho são descritas de forma ordenatória:

Art. 125 - O Corpo de Bombeiros Militar é instituição permanente, organizada com base na hierarquia e na disciplina, cabendo-lhe, entre outras, as seguintes atribuições:

I - a execução de atividades de defesa civil;

II - a prevenção e o combate a incêndios e a situações de pânico, assim como ações de busca e salvamento de pessoas e bens;

III - o desenvolvimento de atividades educativas relacionadas com a defesa civil e a prevenção de incêndio e pânico;

IV - a análise de projetos e inspeção de instalações preventivas de proteção contra incêndio e pânico nas edificações, para fins de funcionamento, observadas as normas técnicas pertinentes e ressalvada a competência municipal definida no Art. 64, incisos $\mathrm{V}$ e VI, e no art. 69, inciso VIII, desta Constituição.

É justamente acerca do Inciso II deste mesmo artigo que foi promulgada a Lei Estadual oㅜ 15.802, de 11 de setembro de 2006, que institui o Código Estadual de Segurança contra Incêndio e Pânico que regimenta as disposições técnicas das instalações de edificações em todo o estado e que durante as exposições das entrevistas serão aqui elencadas como necessárias para a estrutura comercial em que se ocorreu o incêndio.

Por outro lado, durante as exposições serão evidenciadas técnicas e táticas de combate a incêndio recomendadas no Manual de Combate a Incêndio Urbano (2017) do CBMGO de comportamento do fogo, riscos específicos, efeitos nocivos, equipamentos de combate a incêndio, maneabilidade e técnicas de progressão e ataque, ventilação tática e estratégia 
e tática com base no Sistema de Comando de Incidentes (SCI) auxiliado do Procedimento Operacional Padrão ${ }^{6}$ (POP, 2018) do CBMGO para combate a incêndio urbano em edificações comerciais.

Estudos mostram que, a letalidade ocorrida no local dos incêndios em edificações (CORRÊA, SILVA e PIRES, 2017) está relacionada ao aumento da densidade demográfica, período noturno e condições não regularizadas, principalmente residenciais. Acerca da não regulamentação, esta situação pode ser melhor observada, quando se leva em conta um maior número de possíveis vítimas, já que como Curta e Delcros (2010) defendem que as áreas mais propensas ao fogo em todo o mundo, estão quase sempre em áreas vizinhas ao desenvolvimento de atividades humanas, e aqui percebemos bem, nesta comercial atacadista que abrigava cerca de 200 funcionários.

Não foram evidenciados relatos internacionais de estudos de casos semelhantes nas línguas inglesa, espanhola e francesa acerca do evento em contexto, apenas vídeos e notícias trazendo relatos dos trabalhos de combate a incêndio com poucas semelhanças ao fato, devido as diversidades de produtos armazenados e diferenças em relação ao tamanho e tipo de estrutura, e que não levavam em conta o desenvolvimento de matérias com base científica na literatura internacional e o aqui estudado.

\section{DESIGN DO ESTUDO DE CASO}

O estudo de caso em questão contemplou a análise documental que observou os dados de registro de ocorrência no Registro de Atendimento Integrado (RAI), Laudo de Investigação da Perícia de Incêndio (LIPI), Código Estadual de Segurança Contra Incêndio e Pânico e protocolos de combate a incêndio recomendados pela instituição. Foram também realizados levantamentos estatísticos acerca de incêndio estrutural no Corpo de

\footnotetext{
${ }^{6}$ Disponível em POP-Procedimento-Operacional-Padrao.pdf (bombeiros.go.gov.br)
} 
Bombeiros Militar de Goiás (CBMGO) e Corpo de Bombeiros Militar do Distrito Federal (CBMDF), que também auxiliaram no atendimento da referida ocorrência. Acrescentados a estes dados, foram também realizadas entrevistas abertas com integrantes do atendimento operacional da ocorrência que se categorizaram em dois grupos: especialistas (chefes de guarnições) e peritos. No quadro de especialistas elencamos os profissionais com experiência operacional em Instrutor Flashover, Curso de Operações em Incêndio (COI) e motorista especializado em caminhão de incêndio.

O Objetivo norteador do referido estudo de caso era encontrar agravos nas situações de incêndio estrutural que pudessem ser descritos como resultantes do não cumprimento das normatizações e que influenciariam diretamente na proporcionalidade de perca e danos para os proprietários, trabalhadores do local, terceiros, meio ambiente e bombeiros.

Para os últimos, ressaltamos o desgaste ocupacional, adicionado às idealizações de insalubridade, periculosidade e penosidade auferidas na atividade de combate a incêndio estrutural. Tendo como norteador os incidentes envolvendo incêndio em edificações de forma geral que colocam em evidência a perda de vidas humanas e que será observado nas Leis atuais descritas a partir daqui e ressaltadas em negrito nas esferas em que se encontram relacionadas a atividade de combate a incêndio estrutural.

Para este trabalho utilizaremos a definição ${ }^{7}$ de insalubridade, periculosidade e penosidade de Freitas (2017) onde:

O direito a percepção dos adicionais está intimamente ligado aos direitos e garantias fundamentais. Essas evidenciações dos direitos sociais, juntamente com os culturais e econômicos, bem como os coletivos, correspondem a igualdade, e estão ligados aos direitos fundamentais de segunda dimensão, ou seja, possuem núcleo na isonomia, relacionando-se com a ideia de um estado social. (p. 01)

\footnotetext{
${ }^{7}$ Definidas em Lei para o recebimento de pecúnia.
} 
Revista Científica do Corpo de Bombeiros Militar de Pernambuco

Artigo Publicado no Vol.07 N.20 - Edição Especial 2021 - ISSN 2359-4829

Versão on-line disponível em: $\underline{\text { http://www.revistaflammae.com }}$

Mesmo que se perceba uma maior evidência de compreensão

relacionada a ideia de percepção adicional destas condições como visto na CF/1988:

Art. $7^{\circ}$ São direitos dos trabalhadores urbanos e rurais, além de outros que visem à melhoria de sua condição social:

$[\ldots]$

XXIII - adicional de remuneração para as atividades penosas, insalubres ou perigosas, na forma da lei. (Grifo nosso)

Tal situação não impede que se observe de maneira mais acurada as relações ambientais em que se desenvolvem como observado acerca da definição de insalubridade no aparato da Consolidação das Leis Trabalhistas (CLT) em seu Artigo 189:

Art. 189 - Serão consideradas atividades ou operações insalubres aquelas que, por sua natureza, condições ou métodos de trabalho, exponham os empregados a agentes nocivos à saúde, acima dos limites de tolerância fixados em razão da natureza e da intensidade do agente e do tempo de exposição aos seus efeitos. (Grifo nosso)

De acordo com Freitas (2017) então, considera-se insalubre:

aquilo que causa dano a saúde do empregado e também a sua integridade física. Também são considerados insalubres, segundo alguns doutrinadores, os elementos que acarretem alterações psicológicas, sejam decorrentes de pressões ou tensões. Os riscos à saúde do trabalhador podem decorrer de vários fatores, entre eles: os físicos, como temperaturas extremamente altas ou baixas, umidade e ruídos sonoros; os químicos, como é o caso da fumaça e do vapor; e os fatores biológicos, que como exemplo mais clássico, temos os agentes infecciosos que podem causar alguma doença. Há também, como demonstrado, os fatores psicológicos, no caso, por exemplo, as tensões e pressões emocionais. (Grifo nosso)

Já o conceito de adicional de periculosidade, encontra-se disposto na Consolidação das Lei do Trabalho em seu art. 193, onde:

Art. 193: São consideradas atividades ou operações perigosas, na forma da regulamentação aprovada pelo Ministério do Trabalho e Emprego, aquelas que, por sua natureza ou métodos de trabalho, impliquem risco acentuado em virtude de exposição permanente do trabalhador a: 
II - roubos ou outras espécies de violência física nas atividades profissionais de segurança pessoal ou patrimonial. (Grifo nosso)

Assim, e de acordo com (Freitas, 2017):

É periculoso aquilo que causa perigo a vida, sendo que uma atividade ou operação periculosa expõe, de maneira constante, 0 empregado a uma situação que pode a qualquer momento acarretar uma fatalidade. Diferentemente da insalubridade que gera risco à saúde e a imunidade biológica. Foi para listas as atividades consideradas periculosas que o Ministério do Trabalho e Emprego (MTE) emitiu a Norma regulamentar número 16. Desta norma podemos extrair que são consideradas atividades ou operações periculosas aquela executadas com utilização de motocicleta ou motoneta exclusivamente no percurso da residência para o local de trabalho ou deste para aquela; as atividades em veículos que não necessitem de emplacamento ou que não exijam carteira nacional de habilitação para conduzi-los; as atividades em motocicleta ou motoneta em locais privados; as atividades com uso de motocicleta ou motoneta de forma eventual, assim considerado o fortuito, ou o que, sendo habitual, dá-se por tempo extremamente reduzido; as operações de testes de aparelhos de consumo do gás e seus equipamentos ou no transporte de inflamáveis líquidos e gasosos liquefeitos em caminhão-tanque; dentre outras. (Grifo nosso)

Em relação a penosidade a Constituição Federal garante no artigo $7^{\circ}$, inciso XXIII, o direito ao recebimento do adicional de penosidade. Não existe no ordenamento jurídico brasileiro regulamentação dessa norma constitucional por uma lei inferior, portanto, são escassas suas citações no direito comparado, sendo mais interessante recorrer a doutrina e jurisprudência, que também é singela sobre o tema. Trabalho penoso seria então diante destas circusntâncias; aquele " [...] gerador de desconforto físico ou psicológico, superior ao decorrente do trabalho normal" (MAGANO, 1993, p. 242) e que se torna "acerbo, árduo, amargo, difícil, molesto, trabalhoso, incômodo, laborioso, doloroso, rude" (JÚNIOR, 2002, p. 186). Em resumo as atividades consideradas penosas seriam aquelas em que 
Revista Científica do Corpo de Bombeiros Militar de Pernambuco

Artigo Publicado no Vol.07 N.20 - Edição Especial 2021 - ISSN 2359-4829

Versão on-line disponível em: http://www.revistaflammae.com

\begin{abstract}
"Esforço físico intenso no levantamento, transporte, movimentação, carga e descarga de objetos, materiais, produtos e peças; posturas incômodas, viciosas e fatigantes; esforços repetitivos; alternância de horários de sono e vigília ou de alimentação; utilização de equipamentos de proteção individual que impeçam o pleno exercício de funções fisiológicas, como tato, audição, respiração, visão, atenção, que leve à sobrecarga física e mental; excessiva atenção ou concentração; contato com o público que acarrete desgaste psíquico; atendimento direto de pessoas em atividades de primeiros socorros, tratamento e reabilitação que acarretem desgaste psíquico; trabalho direto com pessoas em atividades de atenção, desenvolvimento e educação que acarretem desgaste psíquico e físico; confinamento ou isolamento; contanto direito com substâncias, objetos ou situações repugnantes e cadáveres humanos e animais; trabalho direto na captura e sacrifício de animais (...)".(TRT-2 - RO: 17389020125020 SP 00017389020125020076 A28, Relator: FRANCISCO FERREIRA JORGE NETO, Data de Julgamento: 13/06/2013, 14 ${ }^{a}$ TURMA, Data de Publicação: 21/06/2013). (Grifo nosso)
\end{abstract}

Em entendimento dessas circunstâncias de atuação da atividade de bombeiro de combate a incêndio estrutural a partir das legalizações atualmente observadas quanto a insalubridade, periculosidade e penosidade grifadas aqui durante as últimas descrições do texto, ressaltamos que a seleção dos participantes das entrevistas deu-se ocasionalmente pela participação no referido incêndio, tendo como pressuposto a especialização laboral em Flashover, COI, motorista especialista em veículo de incêndio e Perícia de Incêndio (sujeitos de pesquisa) e o caso estudado é o incêndio estrutural ocorrido num armazém comercial atacadista em 2020 na cidade de Anápolis (GO), sendo que a aplicação de técnicas de combate a incêndio pelos bombeiros do CBMGO será nosso caso de estudo.

O procedimento de coleta de dados efetuou-se primeiramente pelo levantamento bibliográfico acerca do objeto de pesquisa categorizado em bancos de dados brasileiros de teses, dissertações e artigos com ferramentas de busca nas seguintes perspectivas: incêndio, incêndio estrutural, incêndio urbano e incêndio em edificações como demonstrado no Quadro $1^{8}$ :

\footnotetext{
${ }^{8}$ Pesquisa realizada entre os dias 10 e 20 de novembro de 2021 pelo navegador Microsoft Edge.
} 


\begin{tabular}{|c|c|c|c|c|c|}
\hline \multicolumn{6}{|c|}{ Quadro 1 - Levantamento bibliográfico } \\
\hline & Incêndio & Incêndio & Incêndio em & Incêndio & Bibliografias \\
\hline & & Estrutural & Edificações & Urbano & Selecionadas \\
\hline SCIELO & 338 & 28 & 11 & 5 & 4 \\
\hline CAPES & 11.391 & 396 & 164 & 2834 & * \\
\hline $\begin{array}{l}\text { Domínio9 } \\
\text { Público }\end{array}$ & 59 & 0 & 0 & 0 & * \\
\hline $\begin{array}{l}\text { Google } \\
\text { Acadêmico }^{10}\end{array}$ & 215.000 & 47.600 & 29.800 & 60.800 & * \\
\hline SCOPUS & 3 & 21 & 448 & 967 & * \\
\hline LATINDEX & 2 & 0 & 0 & 0 & 0 \\
\hline $\begin{array}{l}\text { Web of } \\
\text { Science }^{11}\end{array}$ & 283.796 & 14.571 & 2.407 & 8.646 & * \\
\hline
\end{tabular}

A escolha por estas bases de pesquisa deu-se num tom de levantamento preliminar do assunto, tendo em vista que o recorte metodológico do tema é multivariado e possui muitos pontos a serem discutidos. Assim, estas bases de dados são as mais conhecidas em termos de criteriosidade em relação as normas mundiais de construção, produção e transmissão de conhecimento. Sendo, portanto, viáveis em termos de pressupostos teóricometodológicos para o estudo de caso em lide.

A pesquisa no SCIELO foi a mais proveitosa em termos numéricos, devido ao tempo de escrita necessário para este artigo e revelou primeiramente que, a maioria dos resultados de pesquisa acadêmica são relacionadas a análise do comportamento de estruturas em situação de incêndio, materiais retardantes e desenvolvimento de materiais para a construção civil que vislumbrem mais segurança nas edificações. Uma parte significante dos

\footnotetext{
${ }^{9}$ Foram selecionadas teses e dissertações apenas na língua portuguesa procurando evidenciar os trabalhos efetuados no Brasil acerca do tema.

${ }_{10}^{10}$ Foram selecionados trabalhos na língua portuguesa e inglesa.

${ }^{11}$ Foram selecionadas em língua inglesa, espanhola e francesa.
} 
resultados, cerca de quase dois terços dos itens pesquisados (193) são literaturas voltadas ao estudo dos incêndios florestais/vegetação com descrição de situações de estado da área queimada, percas ocorridas na fauna e flora com os incidentes de fogo e revitalização das áreas queimadas.

Os setores da Quadro 1 lotados com asterisco foram aqueles que não puderam ser observados ainda para esta pesquisa. Mesmo assim, notou-se nas primeiras observações que a literatura nestes sites de busca acadêmicos voltada para 0 entendimento dos incêndios, formas de combate e desenvolvimento de técnicas é incipiente no contexto brasileiro por mais que se comprove um alto número de trabalhos, fator que nos levou ainda mais a evidenciar o objeto de pesquisa deste trabalho. No contexto mundial, ainda não foi possível efetuar uma pesquisa efetiva devido a nossa necessidade de tempo hábil para escrita.

Há de se ressaltar que, efetuando pesquisas com elementos de análise diferenciados, ou seja, nomes diferenciados na ferramenta de busca como os descritos no Quadro 1, pode-se afirmar que algumas literaturas poderão aparecer constadas em diferentes análises de busca, do mesmo site ou de outro que tenha sido também disponibilizada, tornando o referencial do objeto ainda menos discutido neste ambiente.

As análises documentais acerca do incêndio em estudo foram efetuadas, sobremaneira, levando em conta os dados ofertados no Registro de Atendimento Integrado (RAl), Laudo de Investigação e Perícia de Incêndio (LIPI), Código Estadual de Segurança contra Incêndio e Pânico. A análise das imagens foi efetuada observando um total de 17 vídeos gravados por celular durante a ocorrência por bombeiro habilitado e, mais 01 vídeo gravado ao vivo por drone por civil $^{12}$, com autorização da ANAC. Em somatória, os vídeos alcançaram cerca de 24 minutos de gravações. A análise de cada vídeo foi feita por pelo menos cinco vezes, buscando a melhor imagem que pudesse retratar as condições do incêndio, juntamente com as descrições obtidas

\footnotetext{
${ }^{12}$ Disponível em https://www.youtube.com/watch?v=fYHFlzg21vk\&t=151
} 
através de entrevistas dos bombeiros que estiveram no local e registros documentais.

Os entrevistados foram selecionados levando em conta a participação direta no evento estudado e diferentes especializações. Foram entrevistados: 02 peritos em incêndio, 02 Flashover, 02 COI e 01 piloto/motorista especializado em incêndio. A ideia primordialmente, era confrontar áreas de especializações diferenciadas e observar como cada bombeiro percebe sua atuação, a atuação de outros especialistas e o melhor atendimento ao incêndio como um todo.

Os dados observados em entrevista foram aqueles que apareciam de forma recorrente nas diversas falas. Foram escolhidos para apresentação os trechos de fala que melhor exemplificavam as situações encontradas nas demais falas e de forma mais consistente e descritiva.

\section{RESULTADOS}

Os incêndios em edificações urbanas representam a segunda maior causa de incêndios no território goiano como aponta a Figura 1. 
Revista FLAMMAE

Revista Científica do Corpo de Bombeiros Militar de Pernambuco

Artigo Publicado no Vol.07 N.20 - Edição Especial 2021 - ISSN 2359-4829

Versão on-line disponível em: http://www.revistaflammae.com

Figura 1 - Ocorrências registradas pelo CBMGO em 2020 e 2021



Fonte: CBMGO

No Distrito Federal, o último levantamento feito acerca de ocorrências envolvendo incêndio urbano foi realizado em 2019 como aponta a Tabela 1:

Tabela 1 - Ocorrências de incêndio urbano no CBMDF em 2019

\begin{tabular}{|c|c|c|c|c|c|c|c|c|c|c|c|c|c|}
\hline Região Administrativa & jan & fev & mar & abr & mai & jun & jul & ago & set & out & nov & dez & TOTAL \\
\hline Brasília & 118 & 114 & 72 & 72 & 121 & 156 & 218 & 313 & 348 & 240 & 151 & 84 & 2.007 \\
\hline Ceilândia & 134 & 63 & 75 & 88 & 109 & 170 & 215 & 280 & 335 & 155 & 92 & 85 & 1.801 \\
\hline Planaltina & 95 & 46 & 29 & 27 & 52 & 144 & 243 & 299 & 305 & 165 & 55 & 44 & 1.504 \\
\hline Taguatinga & 90 & 54 & 62 & 68 & 81 & 140 & 190 & 246 & 226 & 125 & 79 & 73 & 1.434 \\
\hline Gama & 42 & 20 & 25 & 49 & 62 & 108 & 174 & 269 & 278 & 123 & 39 & 53 & 1.242 \\
\hline Samambaia & 50 & 58 & 47 & 60 & 71 & 144 & 178 & 196 & 230 & 128 & 22 & 57 & 1.241 \\
\hline Sobradinho & 65 & 30 & 29 & 35 & 57 & 113 & 165 & 238 & 291 & 143 & 39 & 27 & 1.232 \\
\hline Brazlândia & 22 & 16 & 17 & 32 & 48 & 71 & 154 & 185 & 289 & 124 & 23 & 37 & 1.018 \\
\hline Guará & 50 & 29 & 39 & 35 & 51 & 78 & 132 & 180 & 152 & 119 & 49 & 35 & 949 \\
\hline São Sebastião & 36 & 26 & 18 & 18 & 32 & 59 & 120 & 206 & 237 & 98 & 32 & 31 & 913 \\
\hline Santa Maria & 25 & 23 & 30 & 26 & 37 & 72 & 125 & 181 & 149 & 85 & 34 & 44 & 831 \\
\hline Paranoá & 42 & 21 & 15 & 22 & 28 & 46 & 119 & 152 & 144 & 75 & 31 & 29 & 724 \\
\hline Águas Claras & 24 & 48 & 35 & 47 & 44 & 51 & 50 & 92 & 157 & 73 & 32 & 29 & 682 \\
\hline Recanto das Emas & 22 & 10 & 21 & 30 & 30 & 55 & 81 & 154 & 118 & 59 & 26 & 29 & 635 \\
\hline Lago Norte & 17 & 13 & 7 & 4 & 17 & 27 & 43 & 64 & 81 & 56 & 33 & 15 & 377 \\
\hline Park Way & 15 & 12 & 4 & 8 & 17 & 19 & 63 & 54 & 120 & 46 & 9 & 10 & 377 \\
\hline Riacho Fundo & 19 & 14 & 3 & 15 & 21 & 16 & 51 & 65 & 53 & 29 & 27 & 6 & 319 \\
\hline Lago Sul & 25 & 3 & 14 & 7 & 15 & 19 & 48 & 59 & 43 & 44 & 15 & 13 & 305 \\
\hline Sobradinho II & 13 & 9 & 4 & 20 & 18 & 20 & 40 & 47 & 79 & 29 & 7 & 12 & 298 \\
\hline Núcleo Bandeirante & 11 & 20 & 15 & 11 & 18 & 22 & 33 & 32 & 58 & 34 & 9 & 15 & 278 \\
\hline SCIA e Estrutural & 14 & 19 & 9 & 7 & 8 & 17 & 36 & 58 & 46 & 42 & 4 & 12 & 272 \\
\hline Vicente Pires & 5 & 14 & 11 & 6 & 25 & 20 & 36 & 42 & 48 & 29 & 8 & 5 & 249 \\
\hline Itapoã & 20 & 8 & 15 & 11 & 17 & 19 & 31 & 47 & 23 & 18 & 8 & 13 & 230 \\
\hline Riacho Fundo II & 13 & 3 & 11 & 13 & 16 & 25 & 41 & 43 & 27 & 18 & 5 & 8 & 223 \\
\hline SIA & 2 & 10 & 7 & 4 & 5 & 22 & 16 & 31 & 24 & 15 & 8 & 8 & 152 \\
\hline Sudoeste & 2 & 5 & 10 & 3 & 3 & 2 & 14 & 9 & 34 & 15 & 10 & 10 & 117 \\
\hline Cruzeiro & 4 & 5 & 14 & 2 & & 9 & 11 & 18 & 12 & 21 & 5 & 7 & 108 \\
\hline Varjão & 9 & 9 & 6 & & 4 & 9 & 7 & 21 & 17 & 19 & & 3 & 104 \\
\hline Jardim Botânico & 7 & & & 1 & 2 & 11 & 20 & 14 & 27 & 9 & 2 & & 93 \\
\hline Candangolândia & 5 & & 7 & 2 & 4 & 10 & 6 & 19 & 19 & 14 & & 3 & 89 \\
\hline Fercal & 4 & 4 & & & 1 & 4 & 4 & 5 & 19 & 6 & & 1 & 48 \\
\hline TOTAL & 1.000 & 706 & 651 & 723 & 1.014 & 1.678 & 2.664 & 3.619 & 3.989 & 2.156 & 854 & 798 & 19.852 \\
\hline
\end{tabular}

Fonte: CBMDF 
Mesmo que existam diferenciações quanto ao ano ilustrativo, notamos que o Distrito Federal realizou cerca de 19.852 atendimentos em relação aos 6.423 atendimentos realizados em Goiás nos anos de 2020 e 2021 até o mês de novembro em que se efetuou a escrita deste artigo. Em comparação Goiás realizou em dois anos, um terço do total de ocorrências atendidas pelo Distrito Federal em apenas um ano.

Diante das estatísticas, pode-se pressupor que a experiência profissional do bombeiro do Distrito Federal é estatisticamente superior a goiana. Mas, isto seria um equívoco tendo em vista que, o grau de profissionalização como discutido anteriormente se apregoa no conhecimento e desenvolvimento de uma técnica e ciências específica, as quais ambos os bombeiros de cada estado possuem como especialidade.

Assim, considerando o incêndio em edificação comercial atacadista aqui estudado, situado numa cidade de interior, caracterizado como em galpão, este possuía um formato em $\mathrm{L}$ com um total de área construída de aproximadamente $16.000 \mathrm{~m}^{2}$. Possuía pátio amplo e sem divisas com outras construções, ocupando um quarteirão inteiro. $\mathrm{O}$ armazenamento de materiais se caracterizava pela presença de prateleiras fixas que acomodavam gêneros alimentícios, bebidas, materiais de limpeza, utensílios domésticos variados apresentando uma grande carga de incêndio.

Apresentamos no Quadro 2, um resumo de toda a operação de combate a incêndio que melhor evidencia as circunstâncias de trabalho dos bombeiros, emprego de viaturas e desgaste ocupacional. 


\begin{tabular}{|c|c|c|c|}
\hline \multicolumn{4}{|c|}{ Quadro 2 - Dados gerais da ocorrência } \\
\hline Descrição Operacional/UF & CBMGO & CBMDF & TOTAL \\
\hline Horas de trabalho & 274 & 19 & 293 horas \\
\hline Bombeiros empregados & 58 & 16 & 74 bombeiros \\
\hline $\begin{array}{ll}\text { Viaturas } & \text { operacionais } \\
\text { empregadas } & \end{array}$ & 14 & 3 & 17 viaturas \\
\hline $\begin{array}{ll}\text { Viaturas } & \text { administrativas } \\
\text { empregadas }\end{array}$ & 6 & 0 & 6 viaturas \\
\hline Quantidade de água (litros) & 924.000 & 28.000 & $\begin{array}{c}952.000 \text { litros de } \\
\text { água }\end{array}$ \\
\hline $\begin{array}{l}\text { Quantidade de Líquido } \\
\text { Gerador de Espuma (LGE) } \\
\text { (galões de } 20 \text { litros) }\end{array}$ & 0 & 10 & $\begin{array}{l}10 \text { galões (Aprox. } \\
6600 \text { litros de } \\
\text { espuma) }\end{array}$ \\
\hline Número de vítimas fatais & 0 & 0 & 0 \\
\hline Número de vítimas não fatais & 0 & 0 & 0 \\
\hline
\end{tabular}

No Quadro 3, dispomos a lista de exigências de preventivos para a edificação de acordo com a Lei $15.802 / 2006$ e a realidade encontrada no momento da ocorrência:

Quadro 3 - Descrição do sistema preventivo na edificação

Sistema Preventivo

Acesso de viatura na edificação

Segurança estrutural

Compartimentação horizontal

Sistema de chuveiros automáticos

Segurança estrutural

Controle de materiais de acabamento

Saída de emergência

Brigada de incêndio

lluminação de emergência

Alarme de incêndio

Sinalização de emergência

Extintores* $^{*}$

Sistema de hidrantes*

Sistema de Proteção Contra Descargas SIM

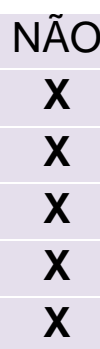

$\mathbf{X}$

$\mathbf{x}$

$\mathbf{x}$

$\mathbf{X}$

$\mathbf{x}$

$\mathbf{X}$

$\mathbf{x}$

$\mathrm{X}$

$\mathbf{X}$ 
Revista Científica do Corpo de Bombeiros Militar de Pernambuco

Artigo Publicado no Vol.07 N.20 - Edição Especial 2021 - ISSN 2359-4829

Versão on-line disponível em: $\underline{\text { http://www.revistaflammae.com }}$

Atmosféricas (SPDA)

Hidrante urbano

$\mathbf{X}$

Fonte: CBMGO

Elaboração: própria

Os sistemas preventivos em asterisco: extintores e sistema de hidrantes existiam na edificação, mas ofereciam problemas. Os extintores não apresentavam nota fiscal atualizada e, não se sabia ao certo, se a quantidade e distribuição dos mesmos, atendiam às normas relacionadas ao tipo de material, tamanho e disposição arquitetônica. O sistema de hidrantes não funcionou por falta de energia na bomba propulsora, visto que, não era independente sua alimentação elétrica daquela de consumo geral. A reserva técnica de incêndio possuía aproximadamente 31 metros cúbicos, sendo que a exigida em norma para a edificação seria de 96 metros cúbicos de água, mais que o triplo observado no local.

Diante destes dados, passemos agora a exposição fotográfica e de relatos dos participantes no trabalho de extinção do referido incêndio. Nas Figuras 2, 3, 4 e 5 temos as primeiras imagens feitas por drone no local do evento, em quatro focos diferentes, ressaltando a dimensão que se tomou 0 incêndio aqui estudado.

Figura 2 - Imagem lado Sul

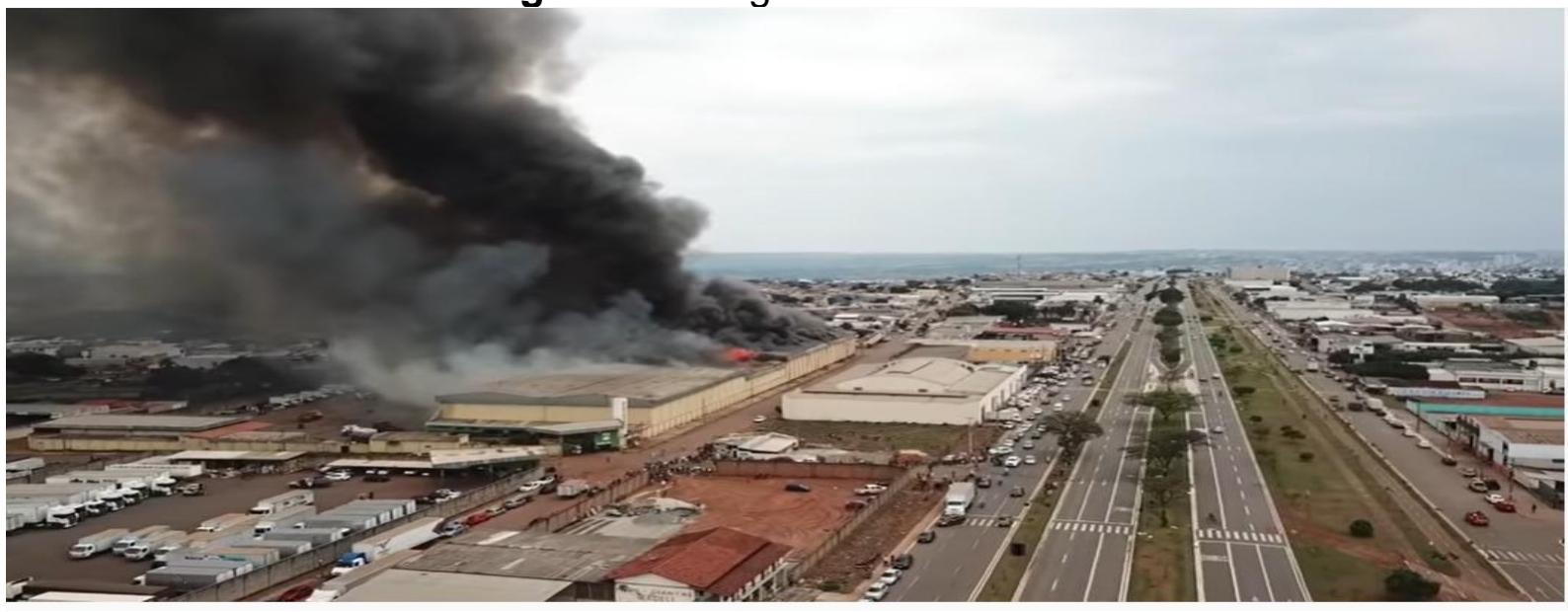

Fonte: https://www.youtube.com/watch?v=fYHFlzg21vk\&t=151

$\mathrm{Na}$ Figura 2 observamos a magnitude do incêndio, com base no tamanho das áreas adjacentes e na espessura de fumaça vista mesmo a longa 
Revista Científica do Corpo de Bombeiros Militar de Pernambuco

Artigo Publicado no Vol.07 N.20 - Edição Especial 2021 - ISSN 2359-4829

Versão on-line disponível em: http://www.revistaflammae.com

distância. Já na Figura 3 observamos em melhor dimensão a área menos atingida pelas chamas e com maior extensão. Nota-se um flanco de chamas altas, superior ao nivelamento do teto da estrutura, o que permite predizer a dificuldade de extinção delas.

Figura 3 - Imagem lado leste

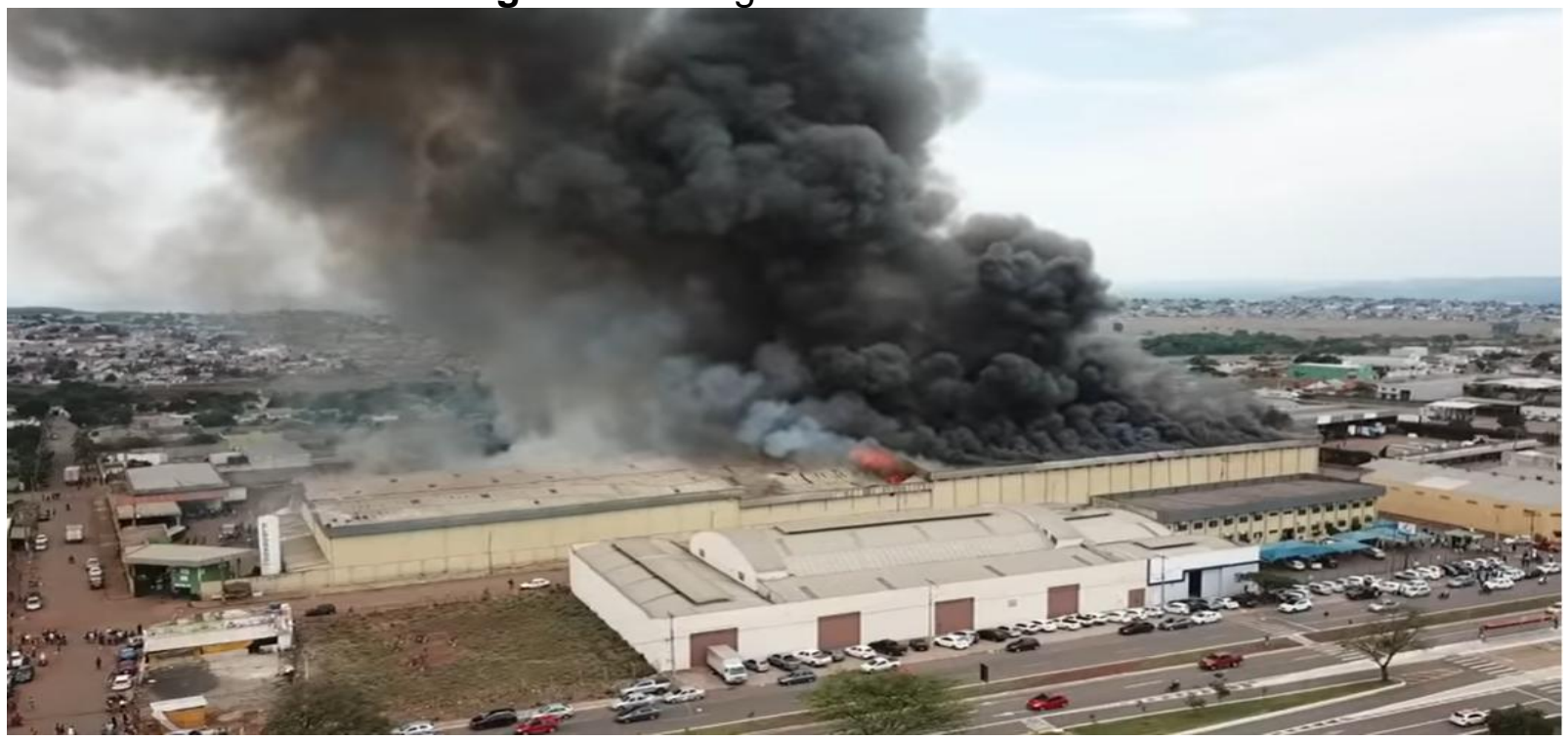

Fonte: $h$ https://www.youtube.com/watch?v=fYHFlzg21vk\&t=151

$\mathrm{Na}$ Figura 4 temos a imagem de bastante fumaça e do local onde relatos afirmaram ter se iniciado o incêndio. Percebe-se que a fumaça mais densa se encontra em todas as direções caracterizando o processo de pirólise onde há queima dos materiais que não possuem mais vapor d'água para queimar. A fumaça branca vista apenas em poucos lugares representa a queima de materiais no incêndio onde há umidade a ser evaporada pela queima no processo de hidrólise de acordo com o Manual de Combate a Incêndio (2017) dependendo do estágio do incêndio. Nota-se também o direcionamento do vento noroeste que impulsionou as chamas e correntes de fumaça quente para as laterais do galpão, acelerando ainda mais o processo de queima e descontrole da situação. 


\section{Revista FLAMMAE}

Revista Científica do Corpo de Bombeiros Militar de Pernambuco

Artigo Publicado no Vol.07 N.20 - Edição Especial 2021 - ISSN 2359-4829

Versão on-line disponível em: http://www.revistaflammae.com

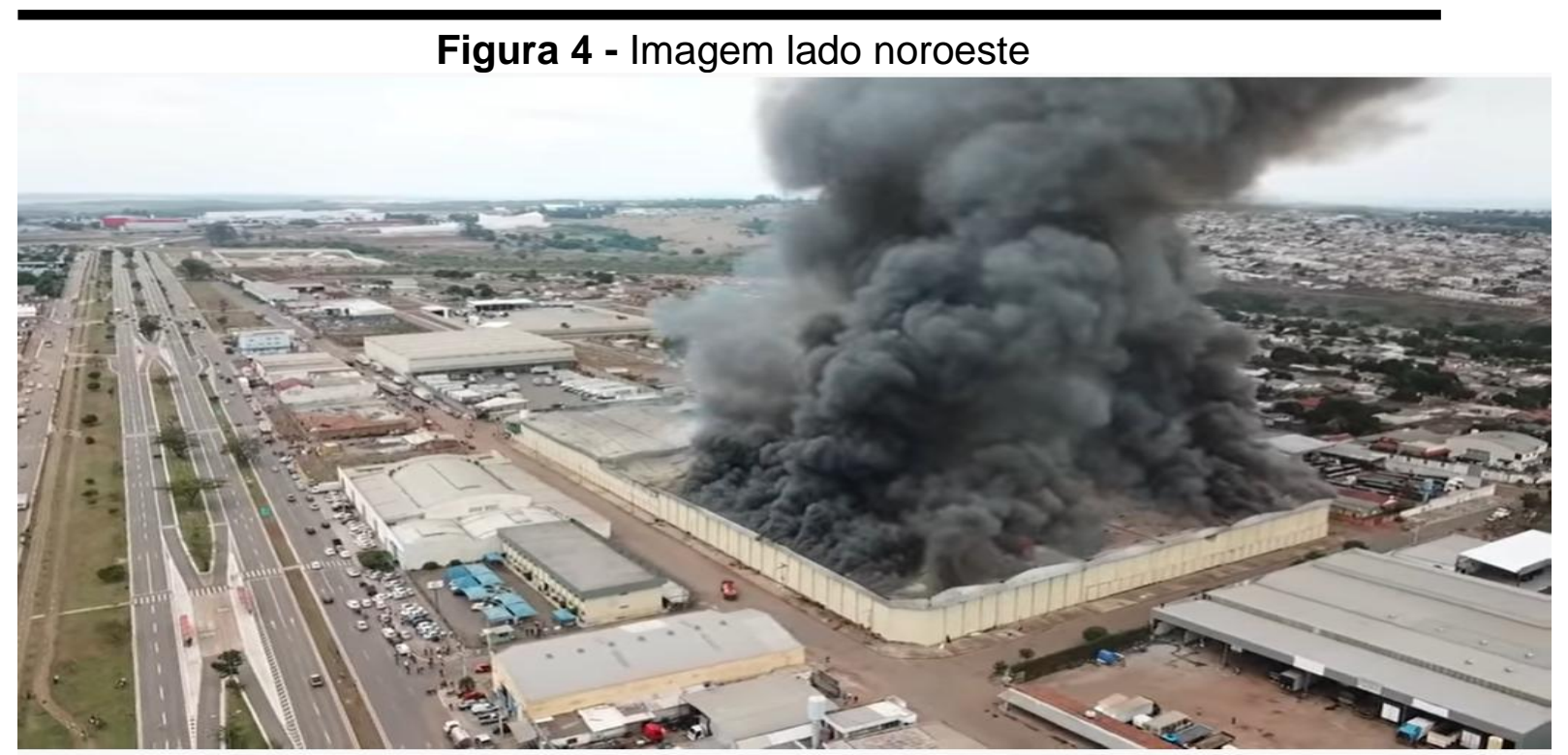

Fonte: https://www.youtube.com/watch?v=fYHFlzg21vk\&t=151

$\mathrm{Na}$ Figura 5, temos em evidência a parte menor do L, onde, da mesma forma que a Figura 3, aparecem chamas acima da altura do teto da estrutura, fator imprescindível para caracterizar o incêndio como tomado em totalidade 0 ambiente e alimentado na parte anterior e posterior, pela presença de chamas no meio das duas zonas de queima.

Figura 5 - Imagem lado norte

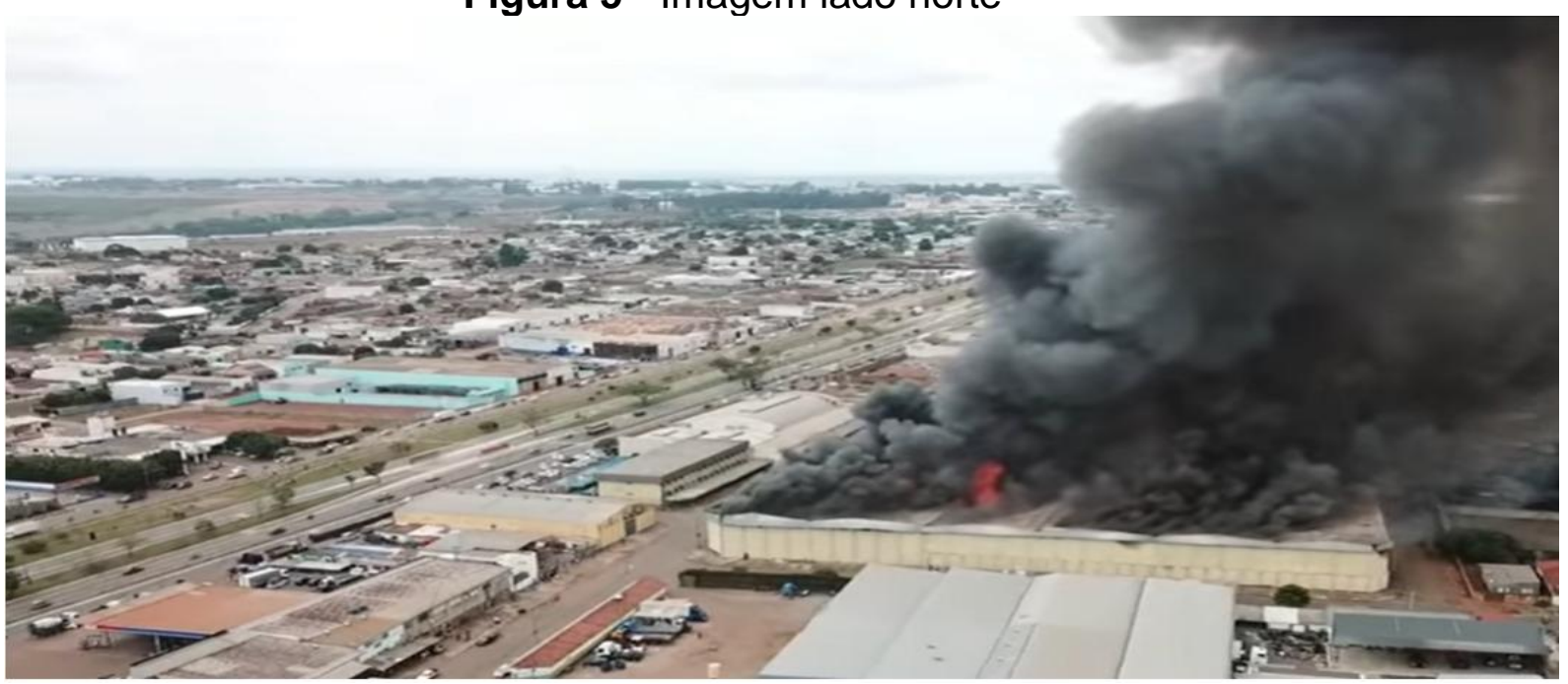

Fonte: https://www.youtube.com/watch?v=fYHFlzg21vk\&t=151

Nas Figuras 6 e 7, temos a imagem mais distante da fumaça, que evidencia a parte ainda não tomada por chamas, mas que apresenta em 


\section{Revista FLAMMAE}

Revista Científica do Corpo de Bombeiros Militar de Pernambuco

Artigo Publicado no Vol.07 N.20 - Edição Especial 2021 - ISSN 2359-4829

Versão on-line disponível em: $\underline{\text { http://www.revistaflammae.com }}$

algumas saídas de ar do teto a presença de fumaça menos densa, mas que principia o aquecimento do local e de seus materiais, ou mesmo surgimento de focos de incêndio por condução, irradiação e/ou convecção.

Figura 6 - Imagem sudeste do incêndio

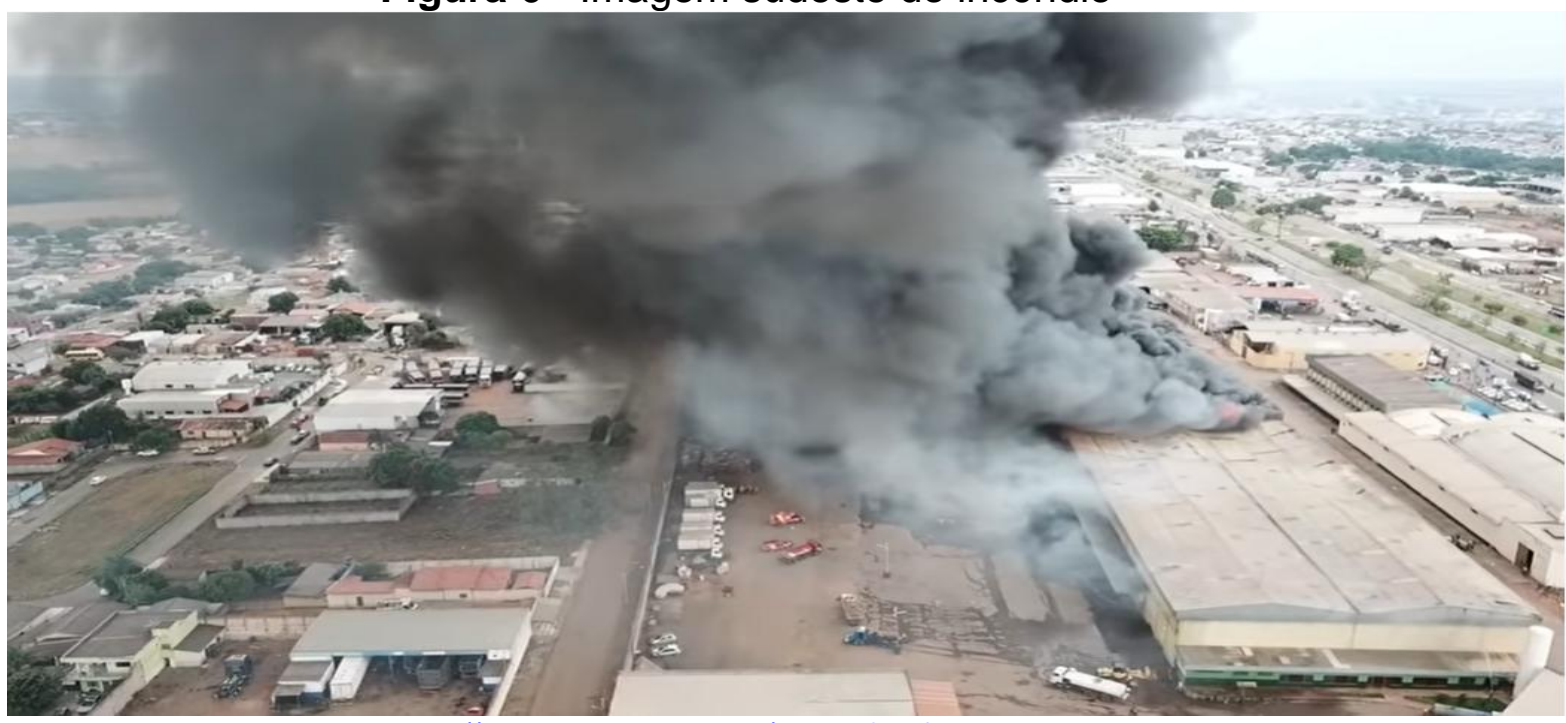

Fonte: $\underline{\text { https: } / / \text { www.youtube.com/watch?v=fYHFlzg21vk\&t=151 }}$

Percebe-se que a área não queimada em proporção visual é cerca de apenas um terço da área de todo o galpão, levando em conta que a estrutura em separado observada no canto esquerdo inferior é um local destinado a abastecimento de automóveis com a existência de compressores de ar para o trabalho com caminhões, utilizados sobremaneira para transporte de produtos. 


\section{Revista FLAMMAE}

Revista Científica do Corpo de Bombeiros Militar de Pernambuco

Artigo Publicado no Vol.07 N.20 - Edição Especial 2021 - ISSN 2359-4829

Versão on-line disponível em: http://www.revistaflammae.com

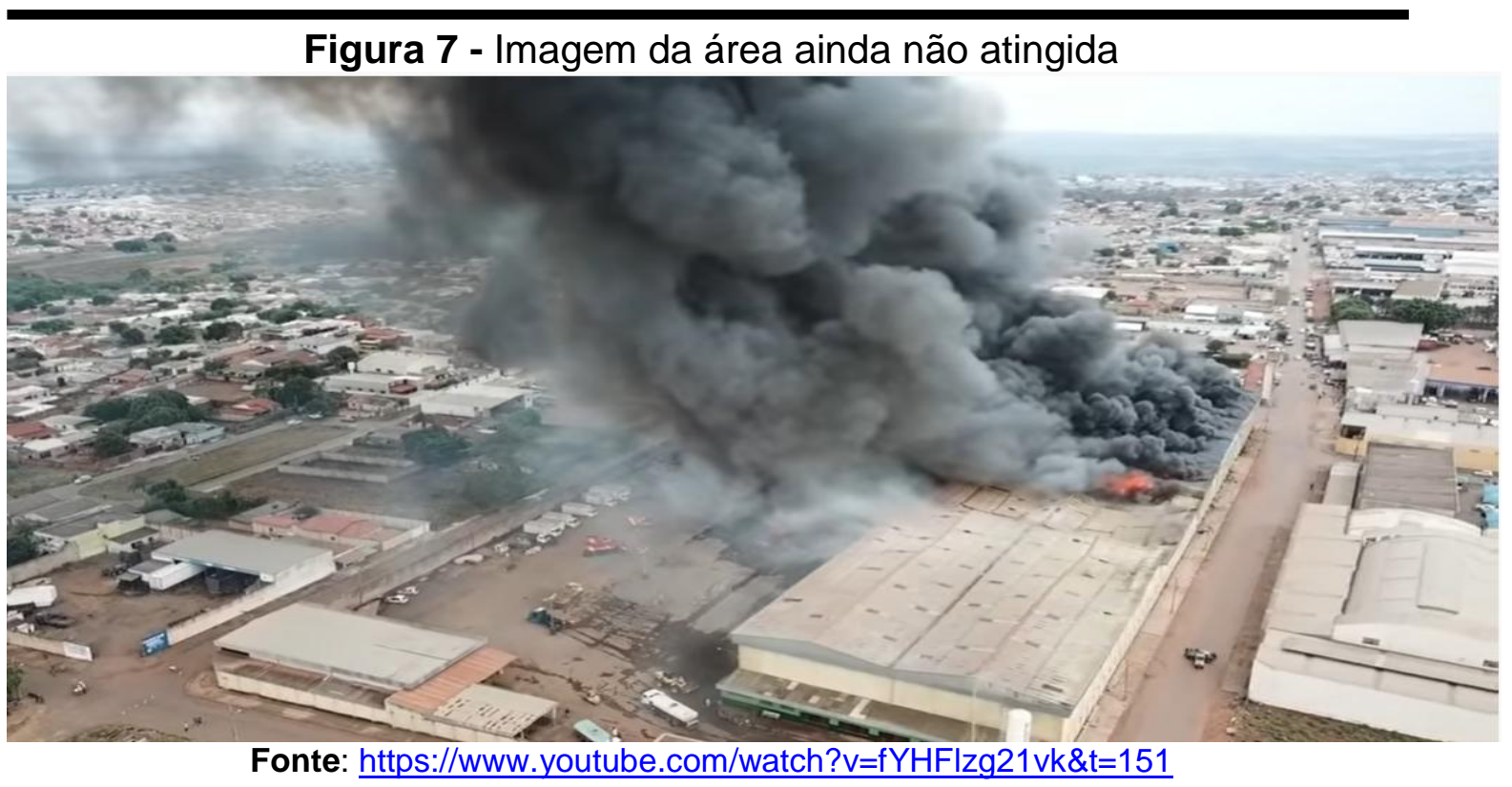

$\mathrm{Na}$ Figura 8, destaca-se o aquecimento do teto nas partes próximas as chamas e mais um pouco distantes, demonstrando que em toda a construção não se observa compartimentação de áreas, fator imprescindível para confinamento de incêndios, sejam eles em princípio, como também em processo de queima.

Figura 8 - Aquecimento do teto e não compartimentação da área

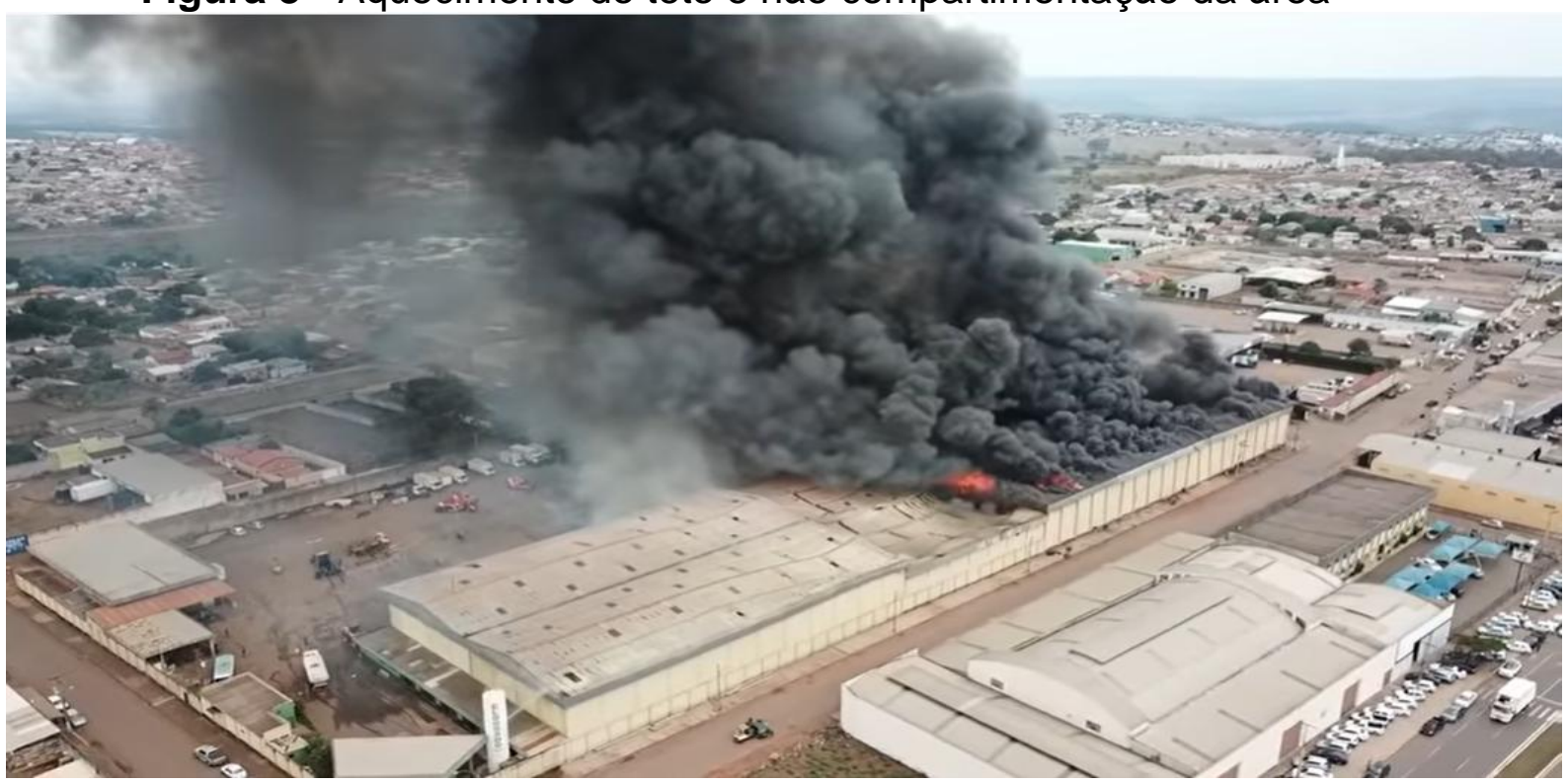

Fonte: https://www.youtube.com/watch?v=fYHFlzg21vk\&t=151 


\section{Revista FLAMMAE}

Revista Científica do Corpo de Bombeiros Militar de Pernambuco

Artigo Publicado no Vol.07 N.20 - Edição Especial 2021 - ISSN 2359-4829

Versão on-line disponível em: $\underline{\text { http://www.revistaflammae.com }}$

Na Figura 9, tem-se a visão mais próxima do incêndio por cima, levando em conta que esta foi a visão mais segura para o drone, tendo em vista, que o mesmo assinalou zona de perigo por calorímetria. Observa-se nitidamente, cinco formações de chamas altas e producentes possíveis de serem extinguidas apenas com plataforma aérea.

Figura 9 - Imagem dos focos de incêndio com chamas principais

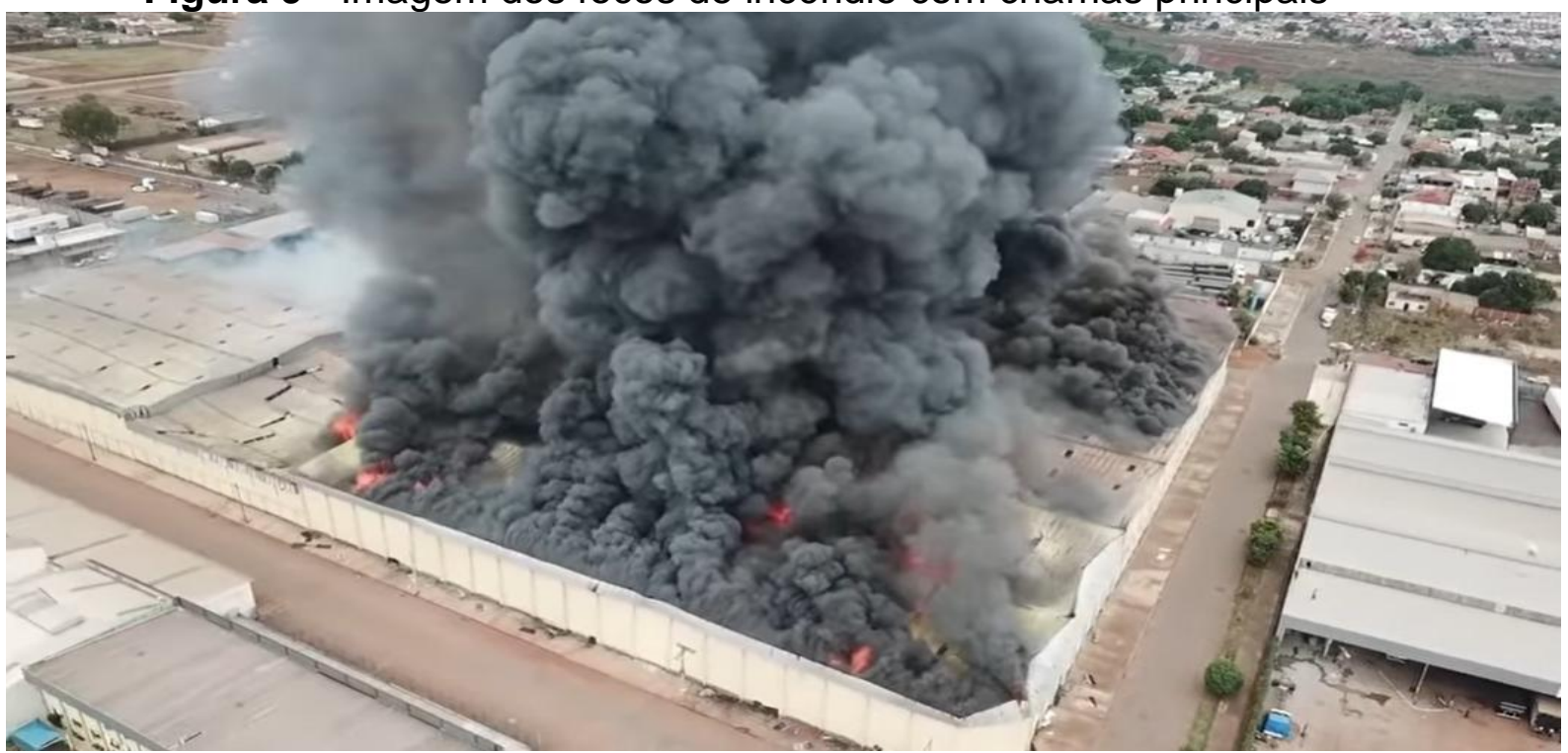

Fonte: $\underline{h t t p s: / / w w w . y o u t u b e . c o m / w a t c h ? v=f Y H F l z g 21 v k \& t=151 ~}$

Na Figura 10, tem-se a ideia do tamanho real das chamas.

Figura 10 - Tamanho das chamas em vista superior

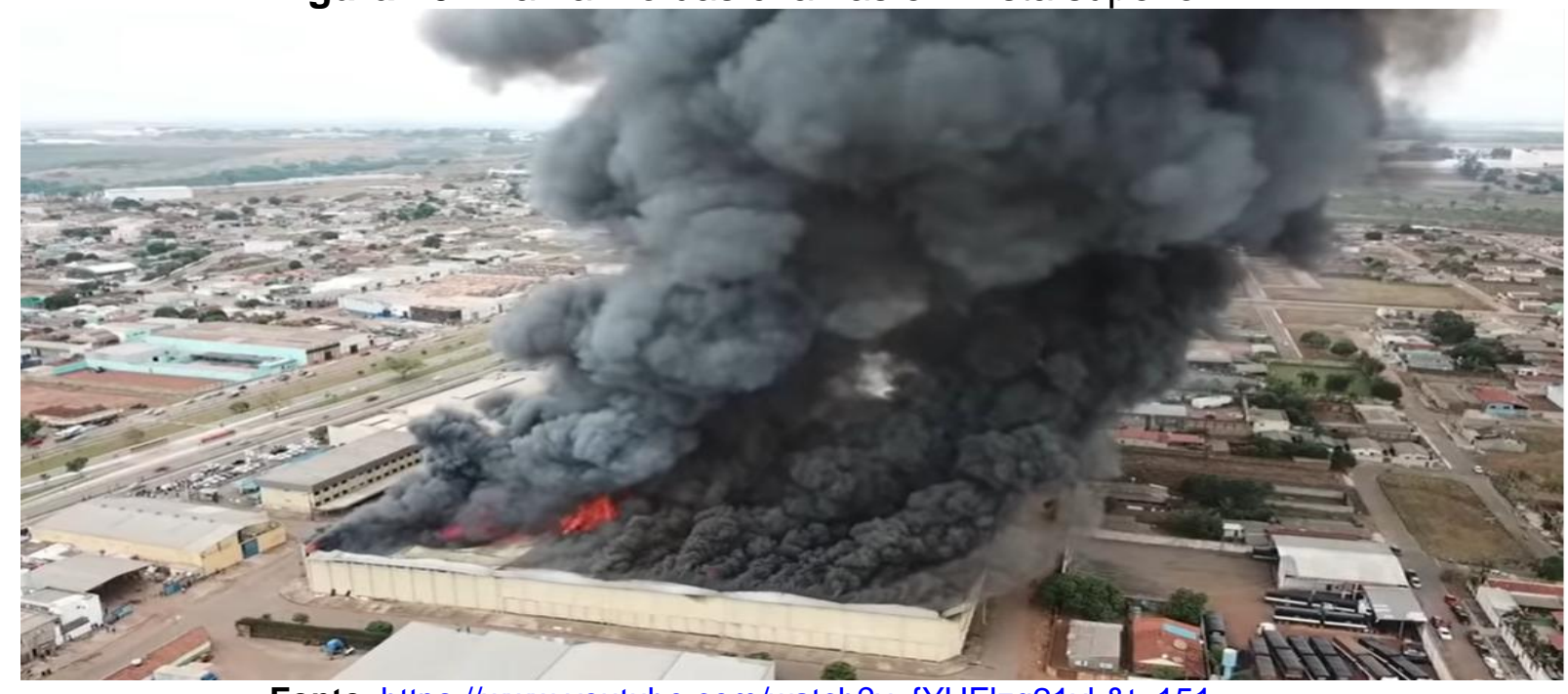

Fonte: https://www.youtube.com/watch?v=fYHFlzg21vk\&t=151 
BOMBEIRO 1 - Quando houve a solicitação via COB (Centro de Operações dos Bombeiros) nós partimos de imediato para lá. Quando nós entramos no caminhão que olhamos para o céu, para o lado do endereço da ocorrência, notamos um feche de fumaça preta enorme. Aí pensamos: Será que tudo aquilo é lá? Então, nós partimos em direção ao local e quando fomos chegando perto, que nós vimos a dimensão que era aquele incêndio. Como foi feito algumas filmagens de drone, estava no momento de almoço, por volta de 11:00h e 11:30h da manhã, sol mais forte, umidade do ar mais baixa, com vento, tudo isso ajudou para aumentar ainda mais o incêndio. No local, em virtude da proporção do incêndio buscamos informações e ouvimos comentários de funcionários da empresa que tinha alguém fazendo solda no telhado da empresa momentos antes do incêndio. Já no pátio da empresa, vimos que havia um tanque de combustível não aterrado, mas, suspenso, junto com compressores de ar e próximo ao refeitório e salas de administração e finanças, que tinham os cofres e todos documentos e dinheiro da empresa. Devido como o fogo foi se tomando na edificação, as portas todas fechadas, não tinha ventilação, horário de almoço, apenas um funcionário gerente de supervisão estava dormindo lá, o foco de fumaça foi visto pelos outros funcionários quando já estava saindo pelo teto, um canudo de fumaça preta, o pessoal correu até o local, bateu para que ele abrisse a porta, porque as portas só se abrem por dentro. Se, porventura, os outros funcionários não tivesse visto, certamente esse funcionário que estava dormindo lá seria uma vítima fatal desse incêndio. Os funcionários tentaram conter alguma coisa, só que de acordo com a velocidade né, de propagação das chamas não conseguiram. Não havia um claviculário de chaves na portaria da edificação, nem planta estrutural, nada. As portas trancadas por dentro, também dificultaram muito nosso acesso que se limitou apenas a flancos do incêndio. Procuramos pelo responsável da Brigada de Incêndio para passar detalhes da edificação e maiores informações e soubemos que não havia registro de brigada na empresa, nem $\mathrm{ART}^{13}$ dos compressores, nem tanques de combustível. Tudo isso, se tornou um problema. Um risco qualificado extremamente maior, porque não sabíamos nada sobre o que poderia ocorrer de agravo e em que momento isso poderia acontecer. Como a edificação era em formato $L$, notamos que a parte menor, segundo relato do responsável pelo local, se encontrava o maior risco que eram as bebidas alcoólicas, refeitório, administração, posto de combustível e compressores. Soubemos que o trabalho de solda foi feito na emenda do L, sobre papéis higiênicos e mercadorias secas, vamos dizer assim. Nessa parte também tinha as panelas de pressão [risos] que aquecidas estouravam porque se tornavam vasos de pressão, porque todas vem lacradas fechadas dentro da caixa. Muitas delas foram encontradas

\footnotetext{
${ }^{13}$ Anotação de Responsabilidade Técnica é um documento emitido pelo CREA que garante a formação e capacidade técnica do profissional de engenharia e agronomia (Engenheiro ou Técnico), o qual responde judicialmente pelos seus serviços e dá garantia de conformidade com o Código Civil Brasileiro.
} 
depois no rescaldo, todas destruídas. Sobre o combate propriamente dito, nós efetuamos duas frentes de combate. Uma direta para impedir que o fogo chegasse na área de maior risco e outra com combate direto e indireto, também priorizando evitar que se alastrasse para a área de maior tamanho do $L$, não deixando também de combater em ajuda a outra guarnição que combatia na parte menor do $L$ e mais perigosa, com risco de explosão. As imagens de drone mostravam que o vento estava contra a parte menor de combate do $L$, o que para nós foi muito difícil, pois era a área de maior perigo, e nós estávamos lá, com o fogo a nossa frente com bebidas alcoólicas e atrás de nós 0 posto de combustíveis com tanque externo e compressores.

O relato do Bombeiro 1 presume que na saída do quartel já se mostrava o descontrole da situação de incêndio no local da ocorrência em pouco tempo. Ele também descreve uma técnica bastante eficaz utilizada pela guarnição no local que foi o resfriamento das paredes adjacentes ao incêndio com o uso do jato atomizado (CORREA et al, 2017) já evidenciado cientificamente em estudos com imagens térmicas para retardar o processo de transferência de calor por irradiação/convecção e consequentemente de novas formações de focos de incêndio. De acordo, com o Bombeiro 6 esta situação tornou-se crítica, porque segundo ele:

\begin{abstract}
Bombeiro 6 - Partindo do princípio da edificação em si, a edificação não tinha sistema de segurança contra incêndio nenhum. Como eu trabalho na área de segurança contra incêndio e eu tenho, assim, conhecimento que, se ela tivesse sistema de sprinklers ou sistema de compartimentação horizontal como é exigido, diminuiria muito nosso trabalho. A compartimentação concentraria o incêndio numa pequena área, como lá era depósito e em depósito a cada $4.000 \mathrm{~m} 2$ se cobra a compartimentação e lá era uns $16000 \mathrm{~m}^{2}$, então, você concentraria o incêndio numa área menor de $4.000 \mathrm{~m}^{2}$. Você reduziria o tempo de atendimento incêndio. Outra forma, o sprinkler que, quando é evidente pegasse fogo estouraria o bico dos sprinklers, se combateria o incêndio no início também, e se mesmo que não apagasse todo o incêndio, mas bombeiro poderia chegar a tempo de conseguir combater e eles não teriam a perda total do material como eles tiveram né. A única coisa que eles tinham eram extintores, eles não tinham sistema de hidrante nem sistema de sprinkler. Então, se eles tivessem um dos mecanismos que é previsto na nossa norma de segurança contra incêndio, teria reduzido a perda deles, o prejuízo e o nosso trabalho seria bem menos perigoso, porque você concentraria o incêndio num espaço menor né.
\end{abstract}

Outro fator relevante segundo os bombeiros que atuaram na ocorrência foi a questão do acesso ao local do incêndio caracterizado como muito difícil, pois as portas mais próximas não tinham abertura para fora, ou seja, todas 


\section{Revista FLAMMAE}

Revista Científica do Corpo de Bombeiros Militar de Pernambuco

Artigo Publicado no Vol.07 N.20 - Edição Especial 2021 - ISSN 2359-4829

Versão on-line disponível em: http://www.revistaflammae.com

estavam trancadas por dentro e o local onde se encontrava o maior foco não possuía portas como mostrado na Figura 11:

Figura 11 - Local de concentração do fogo e formas de adentramento

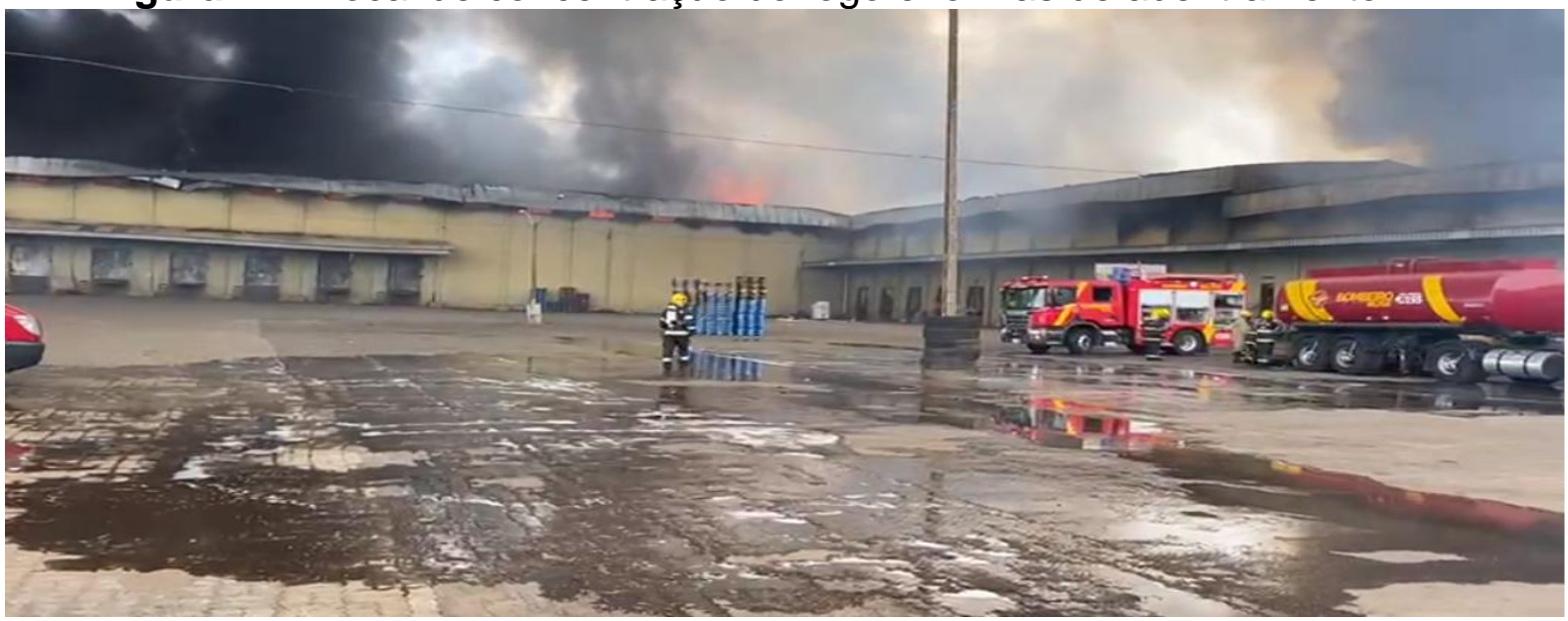

Fonte: Autores

Em todos os relatos este fator apareceu como agravante, pois segundo o Bombeiro 1, "quanto mais rápido se alcançasse o foco principal, mas se evitaria a dimensão do incêndio". Como não se tinha acesso ao referido local, efetuou-se o "arrombamento das portas, o que de outra forma também aumentou o fluxo de ar e abastecimento das chamas porque não se podia efetuar o fechamento das portas já que as mesmas haviam sido arrombadas", como mostra a Figura 12:

Figura 12 - Arrombamento das portas rolantes

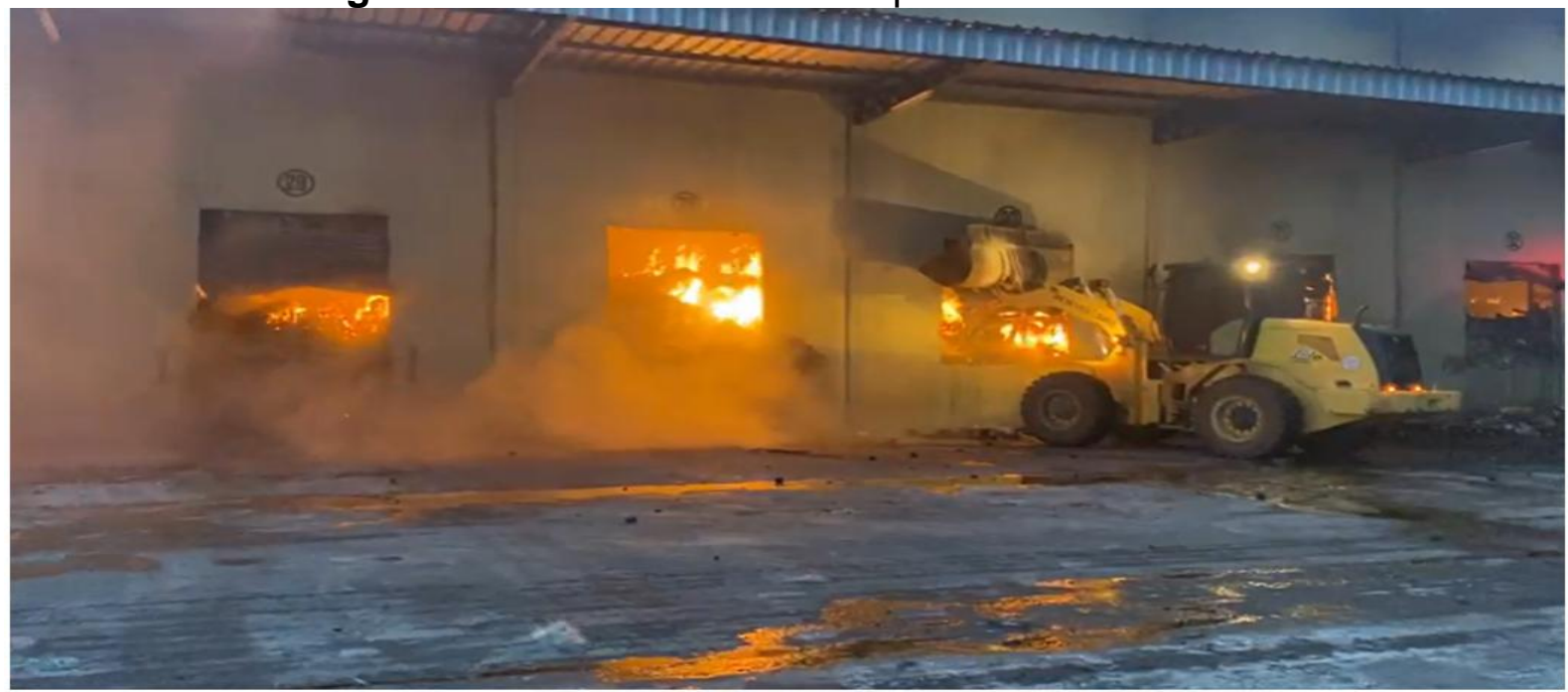

Fonte: Autores 
Aberturas superiores nas paredes externas da estrutura foram feitas para minimizar, após o combate, a temperatura ambiente e a dissipação da fumaça, auxiliando no processo de rescaldo como observado na Figura 13.

Figura 1: Aberturas superiores para retirada de fumaça e diminuição da temperatura ambiente

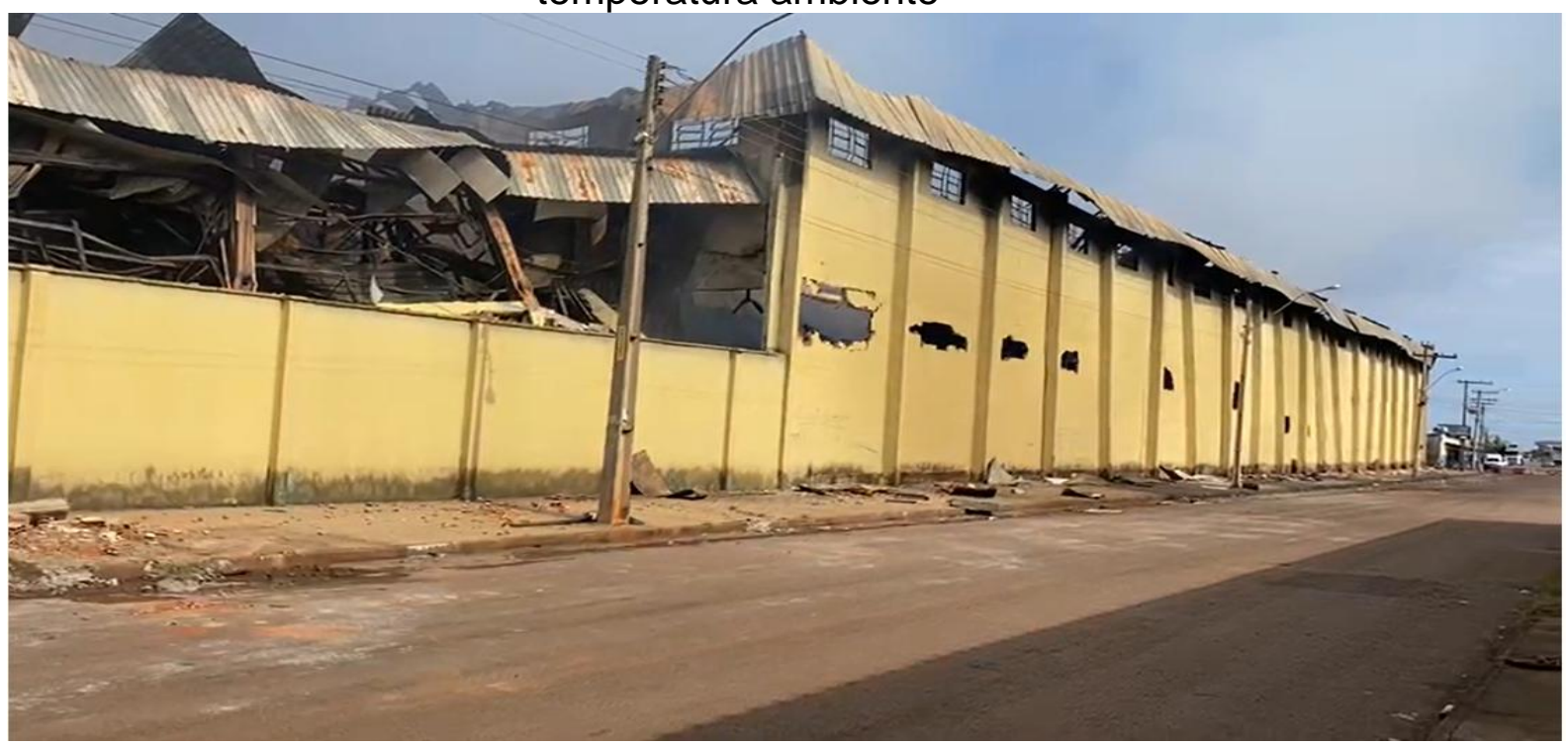

Fonte: Autores

Outro agravante segundo os bombeiros para este incêndio, foi em relação a adentramento para efetuar o rescaldo e o monitoramento para que não se efetuasse novas reignições, segundo eles uma mini retroescavadeira seria ideal para a situação daquela estrutura:

Bombeiro 5 - Quando eu cheguei ao local já tinha cinco dias o incêndio. Verificamos que tinha muito material, a carga de incêndio era muito grande que ainda não tinha queimado, e como a estrutura de ferro do telhado estava caída não tinha como você entrar com a máquina, porque tinha o risco da máquina entrar para retirar, e cair toda aquela estrutura. $\mathrm{O}$ correto seria ter uma Bobcat ${ }^{14}$, ou uma máquina chegar $\mathrm{e}$ retirar o material e jogar tudo para fora e você fazer o rescaldo para evitar novos focos. Mesmo com a Bobcat, teria que ser uma de esteira porque se fosse de pneu ia estourar devido a elevada temperatura no local. Continuamos por causa disso, só fazendo o monitoramento, combatendo onde se via focos, mas mais distanciado da estrutura.

Bombeiro 4 - Agora a questão do rescaldo, como é uma área muito grande muito material e foi por isso que durou tanto tempo, cerca de 10 dias, difícil acesso, quando eles levaram uma máquina maior e

\footnotetext{
${ }^{14}$ Mini carregadeira ou mini retroescavadeira.
} 


\section{Revista FLAMMAE}

Revista Científica do Corpo de Bombeiros Militar de Pernambuco

Artigo Publicado no Vol.07 N.20 - Edição Especial 2021 - ISSN 2359-4829

Versão on-line disponível em: $\underline{\text { http://www.revistaflammae.com }}$

começaram já com a puxar o material com a retroescavadeira grande começaram a ver a estrutura cedendo, não tinha muito espaço para você entrar lá dentro com a retroescavadeira grande.

O perigo de desmoronamento da estrutura foi outro fator que impossibilitou que toda a atividade de extinção do incêndio se efetuasse como ressaltado pelo Bombeiro 5 e observado na Figura 14.

Figura 14 - Situação da estrutura e dificuldade de adentramento

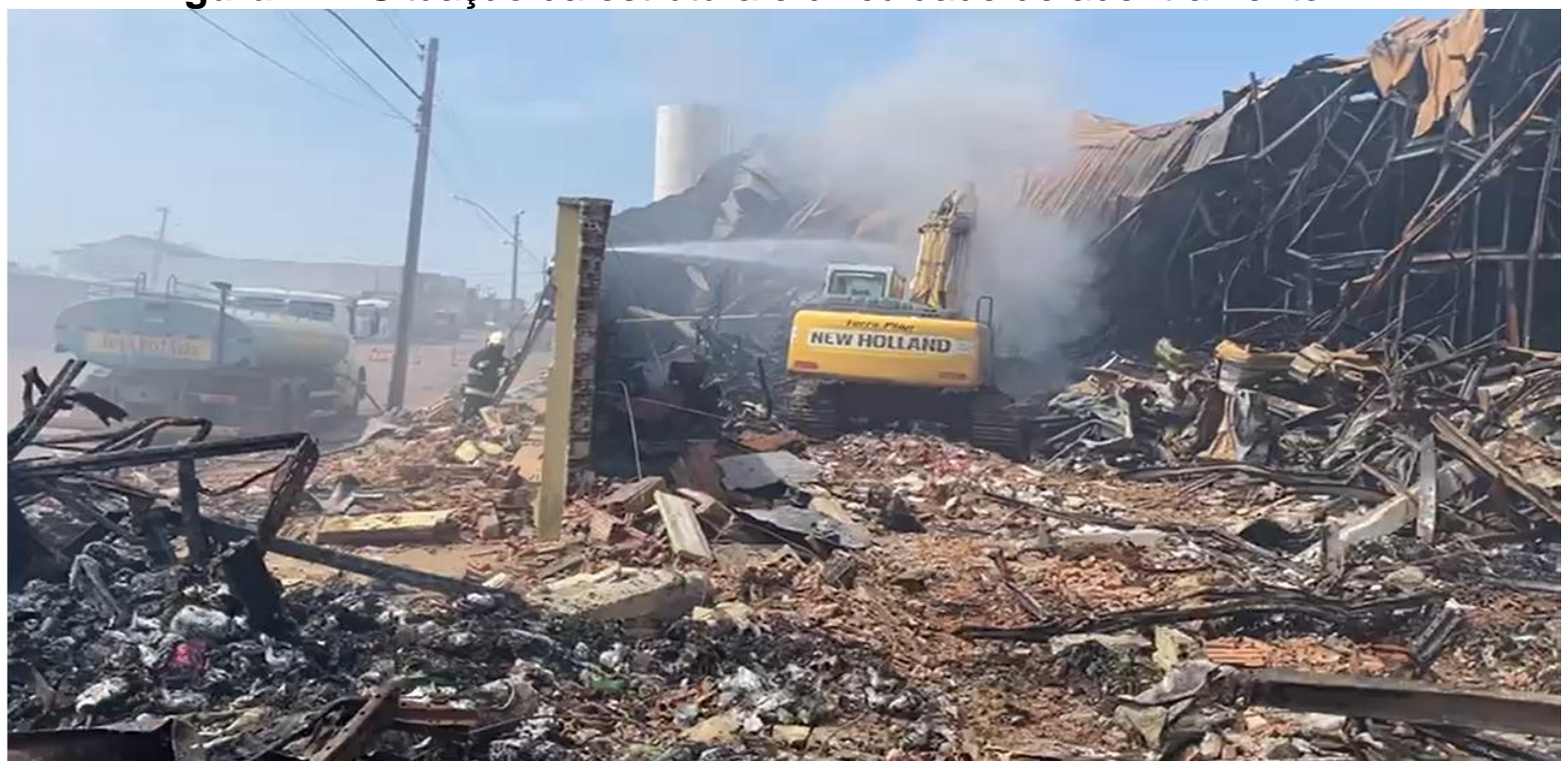

Fonte: Autores

A ideia de se ter uma bobcat pelos bombeiros está diretamente relacionada a forma com que as ferragens estruturais das prateleiras que, eram fixas e estavam impedindo que uma máquina maior efetuasse a retirada de material como observado na Figura 15 e 16. 


\section{Revista FLAMMAE}

Revista Científica do Corpo de Bombeiros Militar de Pernambuco

Artigo Publicado no Vol.07 N.20 - Edição Especial 2021 - ISSN 2359-4829

Versão on-line disponível em: http://www.revistaflammae.com

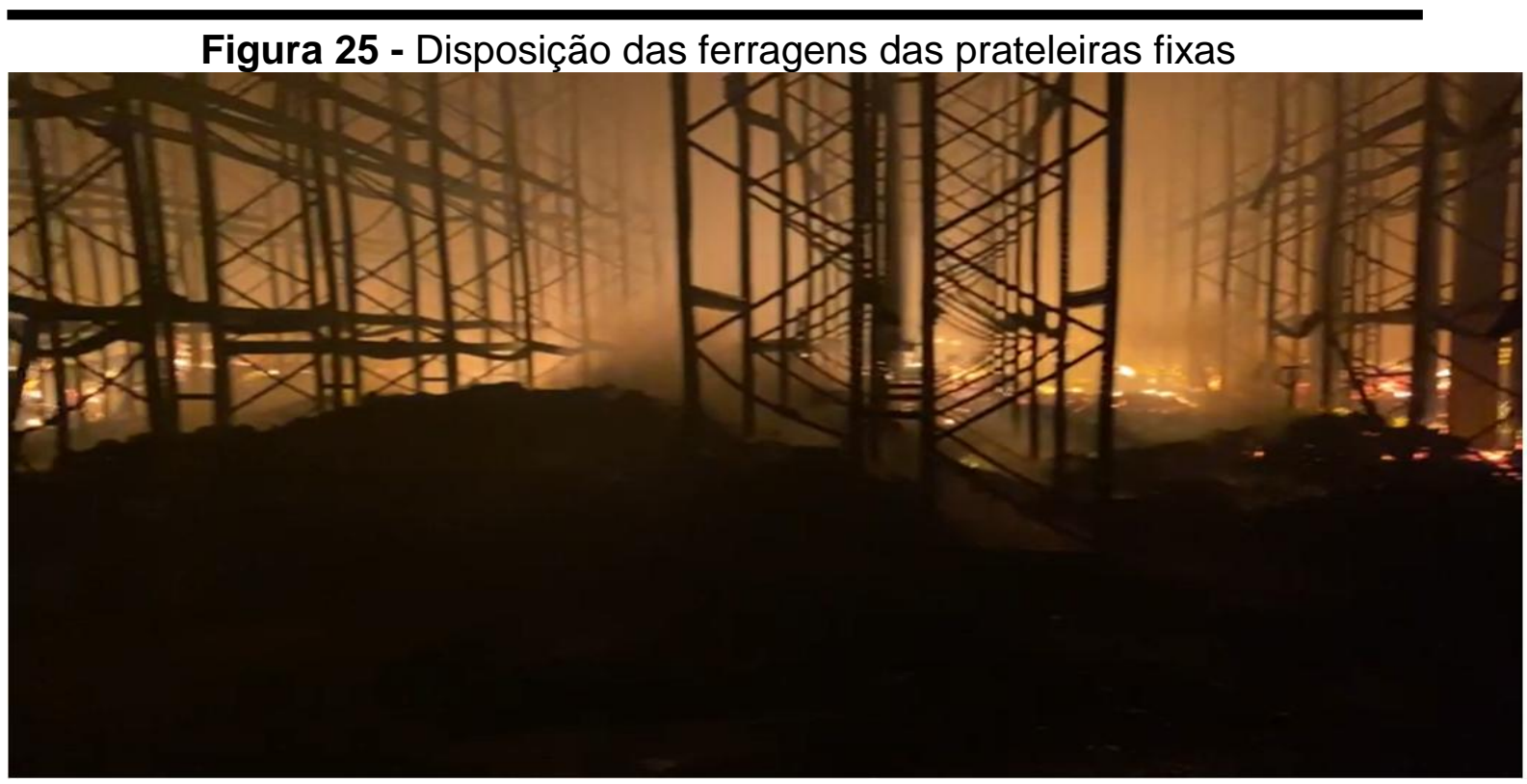

Fonte: Autores

Devido a estas condições o trabalho de rescaldo foi feito manualmente, levando bastante tempo, desgaste ocupacional e risco para os bombeiros, como evidenciado na Figura 16:

Figura 16 - Quinto dia de rescaldo

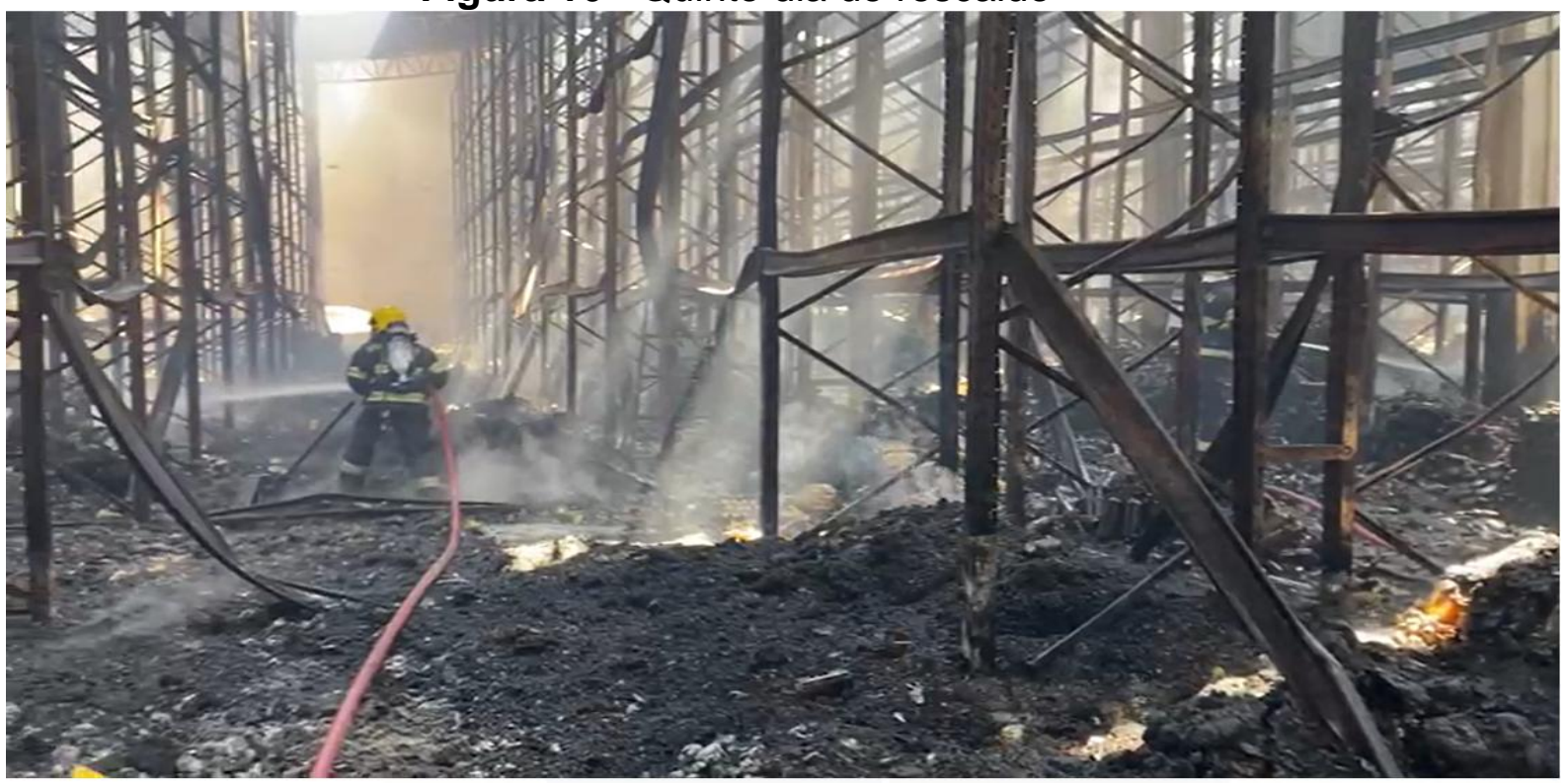

Fonte: Autores

Mesmo que, no segundo dia de combate ao incêndio, houve a ajuda de bombeiros da capital goianiense e do Corpo de bombeiros do Distrito Federal (CBMDF) com plataforma aérea para o auxílio no combate das chamas, 
significativos agravantes, como todos os descritos anteriormente aqui, somaram para a não efetividade da extinção do referido incêndio, principalmente em relação a estrutura do local e deficiência de maquinários alternativos. Uma boa interpretação acerca desta situação, foi descrita pelo bombeiro 7:

\begin{abstract}
$\mathrm{Na}$ verdade, quantos dias exatos eu não sei que eu fiquei atendendo essa ocorrência, mas sei que foi vários dias. Tanto de dia, como a noite. Eu passei a noite lá várias vezes. Eu me lembro muito bem de participar do combate no fogo ali na paste de sabão. Um dos fatores mais complicadores em que eu achei naquele momento é que, além da fumaça, essa fumaça vinha com resíduos de sabão, que era soda né. Isso pinicava muito. Na verdade, a questão efetiva do rescaldo foi outro agravante que eu vi que, quando a gente estava próximo ali para fazer o rescaldo era a dificuldade da incerteza da estabilidade do local a gente sabe muito ferro retorcido, paredes todas rachadas. Então, a gente ainda não tinha uma dimensão ali com a noite do perigo, essa era dificuldade da gente realmente adentrar ao local, de ir com cautela ali revirando alguns material e não se esquecendo dessa situação de perigo ali né. Tinha muito material. Tudo inflamável. Tinha explosões constantemente e o maior perigo era do telhado realmente ali vir a desabar, colocando em risco a integridade física dos bombeiros né.
\end{abstract}

Diante desta descrição e levando em conta, a fala do Bombeiro 1 acerca da descrição do local e das primeiras ações realizadas, observamos que o incêndio alastrou-se rapidamente pela edificação que não continha compartimentação de áreas, fator esse que como apregoado pelo Bombeiro 1 seria imprescindível para confinamento do incêndio e diminuição de sua propagação por meio de combate seletivo de resfriamento de camada de fumaça e de áreas adjacentes ao princípio de incêndio.

A ideia de regulamentação da área devido a sua diversidade de produtos que primeiramente não aparecem como materiais periculosos em contato com o fogo, a substância mais simples pode se tornar um grande fator de insalubridade, penosidade e periculosidade para o trabalho de bombeiros como descrito acima pelo Bombeiro 7. Neste sentido, legalizar o uso de edificações que se encontram com restrições de adequações à legislação de segurança contra incêndio e pânico é tão importante. Primeiro, porque garante segurança a todos envolvidos no trabalho diário da edificação, quanto para os próprios 
bombeiros em caso de incêndio. Segundo, porque isso acarreta menos prejuízos, quando se comparado às perdas materiais num contexto geral como foi observado neste estudo e, terceiro, porque já existem desenvolvimentos de métodos que podem estabelecer a segurança em edificações sem que grandes intervenções estruturais sejam necessárias, modificando ou ajustando-se a fatores que, na verdade, são importantes em caso de incêndio (HAHNEMANN, CORREA, RABBANI, 2017) e que aqui foram grassados como a compartimentalização, brigada de incêndio, hidrantes e/ou sprinklers.

Para o término deste estudo, procuramos evidenciar o trabalho dos peritos de incêndio que efetuam trabalho não apenas no final do incêndio em si, mas durante ele, para entender as caracterizações do local, desenvolvimento do incêndio, das técnicas trabalhadas e coleta de informações gerais que vão desde depoimentos de testemunhas no local a levantamentos de dados históricos da estrutura. Segundo o Bombeiro 3:

\begin{abstract}
O pessoal civil utiliza mais o laudo de perícia de incêndio para questões de recebimento de seguro. Porém, desde quando a gente estuda legislação referente a isso aí e vê no próprio curso de perícia e nos tornamos cientes de que a principal função da perícia do corpo de bombeiros ela é administrativa e não judicial, ela não é criminal né. Então, ela serve para retroalimentar o nosso sistema inclusive em relação a normas, ao próprio serviço de combate a incêndio, a prevenção e, é claro que judicialmente algum magistrado quiser utilizar, ele utiliza também, mas a prioridade não é essa e inclusive a atividade de perito de incêndio ela é necessária para fechar o ciclo operacional do bombeiro, porque sem ela o ciclo operacional não fica fechado. Aí é claro que a gente percebe que alguns, algumas empresas solicitam um laudo no intuito de às vezes fornecer para alguma seguradora, da exigência de seguradoras, nesse sentido.
\end{abstract}

O bombeiro 4 ressalta outra perspectiva em relação ao uso de plataformas e sua eficiência e eficácia diante do rescaldo que foi o período de maior tempo de trabalho dos bombeiros:

Não tem outra forma a não ser com máquinas retroescavadeiras e de forma braçal na enxada, no enxadão que $o$ trabalho literalmente de rescaldo seja feito. Jogando água de fora, na verdade sua objetividade é muito pouca. $\mathrm{Na}$ verdade, não é porque você joga água em cima de um monte ali que está queimando que isso vai acabar com o incêndio. Sabemos que o material sólido queima em profundidade, a tensão da água superficial, ela bate e escorre, ela tira aquela caloria de cima mas embaixo tá queimando. Então, às vezes você tá alagando o local né e ao mesmo tempo não está 
apagando o centro daquele monte ali, daquele material sólido que está queimando em profundidade. Então, os bombeiros realmente tem que ir para cima ali mesmo, tem que revirar na enxada mesmo, revirando somente assim realmente se apaga um incêndio. Lá, as máquinas não conseguia adentrar e tinha muito material ali, muita ferragem, então você tinha que ir mesmo com a enxada para conseguir um resultado satisfatório. Tanto é que choveu bastante numa noite e não resolveu nada e não resolve o serviço, assim, falando tecnicamente de bombeiro, da atividade de bombeiro na verdade. Tem que revirar, resfriar e retirar o material. O serviço de Auto Escada não resolveu, tanto é que choveu no dia que o pessoal de Brasília veio e o serviço de Auto Escada também não era o ideal para o rescaldo. O serviço de Auto Escada tem mais emprego para o início, de combater as chamas ele é bom, mas para o rescaldo o bombeiro tem que adentrar e aí quando eu digo, anteriormente que, tinha um perigo no local, era isso, era a instabilidade do local para a gente adentrar lá e realmente em condições de não nos colocar em risco. Isso porque o fogo já tinha tomado toda a edificação e, também tinham que ter cautela. Tinha que ter primeiro certeza que aquele local oferecia um mínimo de segurança para que a gente pudesse estar adentrando ao local para fazer aquele serviço de rescaldo e conseguir realmente ter objetivo de sanar o problema daquele momento. Tanto é que foram vários dias de rescaldo lá, porque é um trabalho árduo e difícil de ser feito, ainda mais sem a ajuda de máquinas.

Podemos notar que um grande empecilho para que a ocorrência acabasse foi a dificuldade de adentramento não só no início do combate ao incêndio, mas também no trabalho de rescaldo. Um fator preponderante enfatizado por todos os bombeiros entrevistados foi em relação a sempre observar o máximo de segurança possível para a realização das atividades de combate, rescaldo e perícia. Todos os pesquisados envolvidos neste estudo de caso salientaram desgaste operacional, sentimento de insegurança e necessidade de melhoria em número e qualidade dos materiais utilizados pelos bombeiros.

\section{RESULTADOS E RECOMENDAÇÕES}

Diante das exposições deste estudo de caso se torna importante observar os incêndios estruturais em atacadistas como fatores que desencadeiam desgaste ocupacional e grandes perdas materiais e possivelmente, humanas significativas. Sabemos que, os bombeiros são expostos majoritariamente a 
todas as intempéries de um incêndio em larga escala como este que perdurou por cerca de doze dias, tornando-se perigoso, insalubre e penoso em todas as suas fases de atuação.

A saúde ocupacional destes bombeiros deve ser levada em conta também como alicerces para uma maior cobrança para adequações de edificações, pois são eles que mais se desdobram para realizar o trabalho de "vidas alheias, riquezas salvar". São eles os mais afetados por todas as circunstâncias de risco em um incêndio de qualquer porte que se possa observar.

Interessante seria desenvolver trabalhos futuros que levassem em conta 0 uso prático deste estudo de caso e contemplassem formatações legais do desenvolvimento de um maior e melhor poder de polícia a órgãos que possam efetuar uma fiscalização mais eficiente destas instalações e até mesmo, um maior grau de responsabilização aos envolvidos diretamente na direção, chefia ou controle destas instalações em respeito até mesmo a possíveis danos ao meio ambiente como pressuposto, para uma melhor proteção da vida das pessoas que utilizam estes locais como trabalho e dos bombeiros que atuam neles em situação de sinistro e do meio ambiente de forma geral.

Apresentamos alguns direcionamentos acerca da tratativa que evidencia melhor qualidade de trabalho e segurança para os bombeiros que atuam neste tipo de ocorrência, como também, para trabalhos futuros, sugerimos pensar acerca de melhoria de equipamentos como a aquisição de uma mini retroescavadeira, aumento do número de equipamentos de proteção para respiração autônoma e também conscientização da população acerca das técnicas de combate a incêndio que estão em constante mudança e que atualmente não mais preconizam apenas jogar muita água para a extinção do mesmo. 


\section{REFERÊNCIAS}

BOMBEIROS DF. IBOPE: BOMBEIRO É O PROFISSIONAL MAIS CONFIÁVEL PELO 11을 ANO. 15 ago. 2019. Disponível em: < IBOPE: BOMBEIRO É O PROFISSIONAL MAIS CONFIAVEL PELO 11 ANO (bombeirosdf.com.br) > Acesso em 8 nov. 21.

BRASIL. Súmulas. Tribunal Superior do Trabalho. Disponível em http://www3.tst.jus.br/jurisprudencia/Sumulas com indice/Sumulas Ind 2 01 250.htm|\#SUM-228 >. Acesso em: 21 mai. 2017.

BRASIL. Constituição Federal de 1988. Promulgada em 5 de outubro de 1988. Disponível em $<$ http://www.planalto.gov.br/ccivil 03/constituicao/ConstituicaoCompilado.htm >. Acessado em: 18 nov. 2021. [ Links ]

CBMDF. Anuário Estatístico do CBMDF 2019. Março, 2020. Disponível em: < Anuário Estatístico do CBMDF - Acesso à Informacão - CBMDF> Acesso em 19 nov. 21.

CBMGO. Estatística geral do CBMGO 2020-2021. Novembro, 2021. Disponível em: < Estatística e Análise da Informacão - Home (bombeiros.go.gov.br)> Acesso em 19 nov. 21.

CHADUD, Reycilane Carvalho. Os socorristas de resgate bombeiros militares: entre o reconhecimento social e a dinâmica da necessidade. Goiânia: Faculdade de Ciências Sociais: Universidade Federal de Goiás, 2013. (Dissertação de mestrado)

CORREA, C. et al . Incendio en compartimiento de residencia en la Ciudad de Recife: Un estudio experimental. Rev. ALCONPAT, Mérida, v. 7, n. 3, p. 215230, dic. 2017.

<http://www.scielo.org.mx/scielo.php?script=sci_arttext\&pid=S2007-

$68352017000300215 \&$ lng=es\&nrm=iso>.

Acesso

em

18nov.2021. https://doi.org/10.21041/ra.v7i3.221.

CORRÊA, Cristiano, SILVA, José Jéferson Rêgo e PIRES, Tiago Ancelmo. Mortes em incêndios em edificações: uma análise da cidade de Recife no ano de 2011. Interações (Campo Grande) [online]. 2017, v. 18, n. 04 


\section{Revista FLAMMAE}

Revista Científica do Corpo de Bombeiros Militar de Pernambuco

Artigo Publicado no Vol.07 N.20 - Edição Especial 2021 - ISSN 2359-4829

Versão on-line disponível em: http://www.revistaflammae.com

[Acessado 18nov21],

pp.

69-79.

Disponível

em: <https://doi.org/10.20435/inter.v18i4.1116>. ISSN 1984-042X.

https://doi.org/10.20435/inter.v18i4.1116.

CURTA, Thomas; DELCROS, Philippe. Managing road corridors to limit fire hazard. A simulation approach in southern France. Ecological Engineering, v. 36, p. 457-65, 2010.

FREIDSON, Eliot. O renascimento do profissionalismo: teoria, profecia e política. São Paulo. USP, 1988, p.07-129.

FREITAS, Rafael Silva de. Adicionais de insalubridade, periculosidade e penosidade. Jusbrasil, 2017. Disponível em: < Adicionais de insalubridade, periculosidade e penosidade (jusbrasil.com.br) > Acesso em 8 nov. 21.

GOIÁS. Código Estadual de Segurança contra Incêndio e Pânico. Lei oㅡ 15.802. Promulgada em de 11 de setembro de 2006. <Disponível em Lei Ordinária № 15.802/2006 - Casa Civil do Estado de Goiás >. Acessado em: 18 nov. 2021. [ Links ]

. Constituição Estadual de 1989. Promulgada em 5 de outubro de 1989. <Disponível em CONSTITUIÇÃO DO ESTADO DE GOIÁS (goias.gov.br) >. Acessado em: 18nov21. [ Links ]

HAHNEMANN, A.; CORREA, C.; RABBANI, E.. Fire safety evaluation: an alternative method for Brazilian buildings. Rev. ALCONPAT, Mérida, v. 7, n. 2, p. 186-199, agosto $2017 . \quad$ Disponível em <http://www.scielo.org.mx/scielo.php?script=sci_arttext\&pid=S200768352017000200186\&lng=es\&nrm=iso>. Acesso em 18nov.21. https://doi.org/10.21041/ra.v7i2.178.

JÚNIOR, C. Comentários à Constituição Brasileira de 1988. 1991 apud OLIVEIRA, S. G. Proteção Jurídica à Saúde do Trabalhador. São Paulo: LTr, 2002.

MAGANO, O. B.; MALLET, E. Direito do Trabalho na Constituição. 2. ed. Rio de Janeiro: Forense, 1993.

Manual Operacional de Bombeiros: Combate a Incêndio Urbano/ Corpo de Bombeiros Militar. Goiânia: 2017.

NIM. Worldwide ranking: trust in professions. March. 2016. Disponível em: $<$ Worldwide ranking: trust in professions | GfK Compact (nim.org) $>$ Acesso em 19 nov. 21. 


\section{Revista FLAMMAE}

Revista Científica do Corpo de Bombeiros Militar de Pernambuco

Artigo Publicado no Vol.07 N.20 - Edição Especial 2021 - ISSN 2359-4829

Versão on-line disponível em: http://www.revistaflammae.com

SAAD, J. E. D. Consolidação das Leis do Trabalho Comentada. 48. ed.

São Paulo: LTr, 2015. 